\title{
DEVELOPMENT AND SHELTER CHALLENGES OF SMALL ISLANDS: PLANNING WITH A PRO-POOR PERSPECTIVE
}

\author{
Ashok Das* \\ *) Department of Urban and Regional Planning, University of Hawai'i at \\ Mānoa \\ e-mail: ashokdas@hawaii.edu
}

\begin{abstract}
This paper explores why and how small island developing states (SIDS) in the AsiaPacific region should adopt pro-poor policies to overcome development related affordable housing challenges. It first outlines SIDS' common development challenges-small size, remoteness, greater exposure to economic and environmental shocks, and brisk urbanization. In a globalized world, SIDS' developmental and geographic constraints make providing equitable shelter harder. Developing Asia's rapid urban growth and simultaneously widening urban inequality offer hope and sound caution alike for SIDS, whose potential and propensity to attract global investment are unique. Tourism-based economic development is poised to accelerate the private sector's influence on SIDS' land and housing markets. This paper presents the cities of Honolulu (USA), Surabaya (Indonesia), and Dili (Timor Leste) as cases that exemplify, respectively, the advanced, intermediate, and early stages of a possible development continuum for SIDS. Utilizing secondary literature, primary qualitative field-research, news media sources, and observations, it demonstrates that despite common developmental challenges SIDS' diverse governance models and institutional capacities preclude definitive solutions. Instead, it argues for tailored yet flexible policy responses informed by multiple pro-poor principles-inclusivity, affordability, alternative forms of tenure security, and innovative design and construction. Sensitive, contextappropriate adaptation of innovative policy tools that have proven effective in fraught contexts elsewhere (especially, transfer of development rights, inclusionary housing, land pooling/sharing, participatory slum upgrading, and community benefits agreements) can guide SIDS to expand pro-poor shelter provision.
\end{abstract}

Keywords: SIDS, Asia-Pacific, development, tourism, urbanization, pro-poor shelter

\section{INTRODUCTION}

This paper explores why and how small islands developing states (SIDS), especially in the Asia-Pacific region, should develop pro-poor shelter policies to overcome development related affordable housing challenges. Over the last three decades or 
so, the Asia-Pacific region has witnessed the most dramatic drop in poverty levels in modern human history as well as the fastest urbanization (with SIDS of the Pacific sub-region the most urbanized at 71 percent) (UN-HABITAT, 2010). The AsiaPacific almost halved poverty from 49 to 25 percent between 1995 and 2005, and between 1990 and 2010 its urban population increased by 10.7 percent; it now contains over half of the world's megacities, the world's densest cities (on average, over tenfold denser than American cities), and multiple growing megaurban regions (Dahiya, 2012; UN-HABITAT, 2010). Cities are firmly the main engines of growth and prosperity-Asia's 42 percent urban part generates 80 percent of its economic output (Dahiya, 2012). These statistics are no pyrrhic 'triumph' for urbanization apologists (Glaeser, 2012), who recommend even more urbanization and urban density. Yet, the increasing urbanization of poverty and urban inequality outpacing urbanization are disconcerting (Mathur, 2013) for they exacerbate urban spatial inequity and shelter deprivation (Davis, 2007). The issue is even more pressing for SIDS-given how briskly and extensively globalization and neoliberalism are transforming development, and how climate change threats are compounding planning challenges (UN-HABITAT, 2015).

Equitable shelter provision and sustainable spatial development are often more difficult in SIDS because of their unique developmental and geographical constraints - such as small size, remoteness, and greater exposure to economic and environmental shocks. Yet, rapid urbanization and widening urban inequality in Asian cities serve hope and caution at once to SIDS, what with their unique potential and propensity to attract global investment in extractive industries, tourism, and real estate. The paper recognizes that, despite their similarities, any formulaic approach to address SIDS' shelter challenges is precluded by their diversity of governance models and institutional capacities. It emphasizes the need to tailor policy responses that espouse multiple pro-poor principles-inclusivity, affordability, contextual design and construction, sustainability, collaboration among stakeholders and sectors, and alternative forms of tenure security. It is quite likely that the private sector's role in influencing land and housing markets in SIDS through tourism-based economic development will grow bigger. Therefore, the paper asserts that adaptively leveraging relevant innovative policy tools that have been effective in fraught contexts elsewhere-inter alia transfer of development rights, inclusionary zoning, land pooling/sharing, participatory slum upgrading, and community benefits agreements - will prove critical in SIDS, especially in Pacific Island Countries (PICs), for pro-poor shelter provision.

In discussing ideas for shelter policy and planning in SIDS andthe smaller islands of Asia-Pacific's large archipelagic nations to be more effective and propoor, this paper claims to be neither authoritative nor normative, merely instigative. To that end, it draws from the:1) published literature on urbanization, pro-poor shelter innovations, and development challenges for SIDS; and 2) the author's own shelter-related, fieldwork-based research over fifteen years in Asia, plus informed observations from over six years of living in Honolulu, Hawai'i, a premier island tourism destination in the Pacific. To illustrate shelter challenges this paper uses 
Honolulu (USA), Surabaya (Indonesia), and Dili (Timor Leste) as representative cases that exemplify, respectively, the advanced, intermediate, and early stages of a likely development continuum for SIDS.

The paper is organized into six sections. After the introduction, a theoretical framework cum literature review illuminates how forces of economic globalization and other neoliberal impulses vitiate the urban poverty-shelter-resilience nexus, which necessitates the countervailing effect of pro-poor shelter policies. It then delineates SIDS' perennial development challenges, common development trajectories, and potential shelter challenges from increased urbanization and globalization. Next, it delineates and discusses challenges of the shelter sector in the three cases and highlights instructive lessons from each's mitigative attempts or lack thereof. A discussion of innovative shelter policy tools and planning approaches from the Global South and North, potentially relevant for developing pro-poor shelter agendas in PICs, precedes the final summary and conclusions.

\section{THEORY / RESEARCH METHODS}

Claims and debates from literatures pertaining to urbanization; the urban povertyshelter-resilience nexus (i.e. their interrelationships); globalization; and neoliberalism; and pro-poor shelter form the framework within which this paper situates its arguments and recommendations. Persistent urban poverty begets inadequate shelter, which together erode the resilience of communities and cities alike; with little resilience various stresses and shocks can further increase and intensify poverty. These same constraints and challenges are amplified in SIDS. Therefore, to alleviate poverty, improve shelter, and boost resilience, innovative and strong pro-poor approaches are imperative. Urbanization fuels a society's economic growth and progress (Glaeser, 2012). As poor countries move up the development trajectory, urbanization, inevitably, also exacerbates poverty (Martine et al., 2008), proliferating slums and squatter settlements and hampering equitable access to adequate shelter for all (Davis, 2007). As much as Asia's recent urbanization is unmatched, and quite possibly holds the key to ending extreme poverty, it has also wrought massive challenges of pollution, sanitation, environmental degradation, and infrastructure and services provision (Dahiya, 2014). In much of east and southeast Asia, urbanization has considerably increased urban density in existing large and megacities, the spatial spread of urban regions, and the count of small and medium sized cities; urban population growth has been fastest in lower-middle income countries, while upper-middle income countries have experienced the fastest spatial growth (World Bank, 2015).

With its increased scale and pace, migration is now a leading cause of urbanization (Kirbyshire, Wilkinson \& Le Masson, 2017). The urban poor are not all rural migrants, yet significant differences between urban and rural development levels and policies sustain migration to cities for they afford superior access to education, health, information, and jobs (Tacoli, McGranahan \& Satterthwaite, 2015). Also, migrants' contribution to urban population growth is overestimated, but their economic contribution is undervalued (Deshingkar, 2006; Tacoli et al., 2015). 
A unique spatial feature of late Asian urbanization has been extensive periurbanization, often by converting agricultural lands to urban uses, exemplifying rural-urban linkages and transformation. As zones of encounter, conflict, and transformation (Friedmann, 2011), but without proper planning and governance structures, peri-urban areas endure haphazard development, conflicting land uses, spatial inequity, and poor infrastructure (LeGates \& Hudalah, 2014), and frustrate efforts to guide urban growth (Horn, 2014).

A critical facet of this inexorable urbanization has been the urbanization of poverty - during 1993-2002 (Ravallion et al., 2007) the number of extremely poor (living under $\$ 1$ a day) urban dwellers increased by 18 million in South Asia alone, and 50 million worldwide. Although, in the decade up to 2009, Asia improved the lives of 172 million slum dwellers, yet now over half a billion people - i.e. a third of Asia's urban population, and half of the world's slum dwellers-live in slums (UNHABITAT, 2010). This exacerbates urban stresses related to housing and services stresses and disproportionately exposes the poor to them. Many of the developing world's urban poor work and live in the informal sector, whose output is nearly as large as the formal's (Schneider \& Enste, 2016), but formal planning excludes, even condemns, informality (Roy, 2005). Cities are not inclusive of the indigent resident and informal sector worker (Das, 2017); extant urban policies and planning practices overtly marginalize, discriminate, and criminalize the poor, especially migrants (Tacoli et al., 2015; www.righttothecityplatform.org.br). This deepens inequality, as the bulging of Gini coefficients between 1990 and 2005 (e.g. from 26 to 35 percent in China, 34 to 38 in India, and 35 to 40 in Indonesia) evidences (Dahiya, 2012, p. S50).

Development research therefore has posited a livelihoods approachemphasizing the poor's various vagarious assets, and their interconnectedness (Rakodi \& Lloyd-Jones, 2002) - to understand and alleviate poverty (Satterthwaite \& Mitlin, 2014). Systemic exclusion consigns the urban poor to precarious employment and hazardous habitation that raise their vulnerability to economic and environmental shocks. Access to decent shelter directly improves health and security, and raises incomes through rents and home-based enterprises (Tipple, 2005). Extensive levels of prevalent urban poverty and informality, and cities' poor institutional capacity limit adequate and affordable shelter, heighten vulnerability (Rakodi \& Lloyd-Jones, 2002), and weaken urban resilience - the ability to resist and bounce back better from stresses and shocks (Satterthwaite, 2013). Intensifying economic globalization (Griffin, 2003), neoliberalism (Brenner \& Theodore, 2002), and climate change are making it harder to bring urban poverty, shelter, and resilience to balance (Beall \& Fox, 2006).

Urban landscapes and land development, including shelter delivery in developing countries, have transformed considerably following key shifts, in the form of policy experimentation and transfers, induced by neoliberalism and globalization (Harvey, 2001; Peck, Theodore \& Brenner, 2013; Roy \& Ong, 2011). Some challenge the empirical basis of globalization's claim to reduce world poverty (Wade, 2004). The growing influence of global economic forces and flows on local 
housing production seems inexorable: "Housing asset wealth has become an important ingredient of opportunity and inequality [whose] drivers are increasingly global to the extent that local housing market conditions are affected by the degree and nature of the embeddedness of cities and regions within the global economy. A pervasive and sustained house price boom has created a global topography of asset accumulation, housing privilege and risk exposure (Forrest, 2008, p.182)." The worldwide recession of 2008-09, triggered by the American subprime mortgage crisis, exposed the fragility of globally intertwined real estate and financial architectures, with potentially devastating local impacts.

A contested idea, neoliberalism suggests a withdrawal of the state from being an active doer of development and provider of shelter to becoming an enabler of markets (World Bank, 1993) and a facilitator of partnerships with non-state actors (Miraftab, 2004; Plummer 2002) and community participation (Ingham, 1993; Mansuri \& Rao, 2004). Neoliberal ideas and attendant political and structural changes have created new institutional arrangements for governance, planning, and development. Since the 1980s, to reverse adverse development outcomes of centralized top-down planning (Rondinelli, McCullough \& Johnson, 1989), multilateral development agencies aggressively pushed decentralization reforms (Beard, Miraftab \& Silver, 2008), increasingly devolving urban development responsibility and autonomy to cities for promoting good governance (Grindle, 2012). Likewise, public private partnerships (PPPs), citizen participation, and collaboration with civil society organizations (CSOs), such as non-governmental organizations (NGOs), and community-based organizations (CBOs) are expected to deliver shelter and services more effectively, efficiently, and equitably (Das, 2016; Mansuri \& Rao, 2013; World Bank, 2003).

Self-help and limited public provision are often the only available housing choices for the poor in developing countries. Harris and Giles (2003) view the evolution of international housing policies as representing three phases: public housing (1945-1960s), sites-and-services (1972-1980s); and market enablement (1980s to present). Well into the late 1980s many developing countries had very strong but largely ineffective public housing programs (which succeeded in very few countries like Singapore) that discouraged private housing production (Buckley \& Kalarickal, 2005, p. 236). Prior to the 1970s extensive slum demolitions and evictions were the dominant state response (Sumka, 1987). Following John Turner's denouncement of eviction and promotion of self-help (for instance, Turner, 1968, 1976; Turner \& Fichter, 1972), and successful in situ upgrading experiments in Indonesia's slum areas (kampung) (Silas, 1984), the World Bank strongly promoted various slum improvement programs. In sites-and-services programs, entire settlements were relocated to "serviced" sites, at the urban fringe, with basic services, sometimes with partially constructed homes, or even land/property titles (Mayo \& Gross, 1987). These heavily subsidized projects failed at cost-recovery (Mayo \& Gross, 1987), were complicated, destroyed livelihoods and social networks (UN-HABITAT, 2003), and let wealthier occupants gradually push out intended residents (Gilbert, 1997). 
The World Bank's 'enabling markets' phase of the 1990s (World Bank, 1993) emphasized granting private property rights to the poor (de Soto, 1989, 2000) and developing housing finance options for them (Ferguson \& Smets, 2010). Research has now exposed the minimal state's failings in shelter delivery (Werlin, 1999), and also challenged the preponderant notion that titling improves access to credit (Goldfinch, 2015). Across different contexts, there has been a strong resurgence of the role of the state in shelter delivery (Chakrabarty, 2017; Das, 2016; Monkkonen, 2011; Mukhija, 2003), but not always with desirable outcomes. Current wisdom holds the most effective pro-poor shelter intervention to be slum upgrading (UNHABITAT, 2010), which should be done in situ, whenever possible; allow communities and other stakeholders to participate; offer rights to land or tenure security; recognize the needs of renters; help sustain livelihoods; build social capital; and be citywide in scale (UN-HABITAT, 2003). Scholars have exhorted policymakers to reevaluate "assisted self-help" for reviving and prioritizing it in national and local housing policies (Bredenoord \& van Lindert, 2010).

Calls to arrest growing urban inequality and the scarcity of affordable housing through legally guaranteed, explicitly pro-poor housing and land policies are louder than ever before. As a multidimensional concept and a right, a pro-poor shelter approach must: encompass the security of all forms of tenure; protect against forced evictions; grant access to all basic services; ensure habitability through the use of appropriate building materials; protect against natural threats to health and life; be affordable; support access to means of subsistence, resources, and livelihoods; allow participation in all decision-making related to housing; and prioritize the needs of historically marginalized minorities (Rolnik, 2014, p. 294). On September 9, 2016, just weeks prior to the vicennial event, Habitat III, in Quito, national governments agreed for the first time to include the "right to the city" concept in the draft New Urban Agenda. The "right to the city" emerged as a coalesced demand of myriad international civil society groups spearheading urban social-justice campaigns on gentrification, forced evictions, foreclosures, the privatization of public space and the criminalization of homelessness, refugees, etc. The definition of the right to the city included in the New Urban Agenda is somewhat diluted, reflecting a compromise reached after protracted negotiations. Nonetheless, after years of struggle to get states to acknowledge and espouse the concept, most CSOs consider its inclusion a watershed moment in the evolution of shelter policy (http://citiscope.org/habitatIII/news/2016/09/historic-consensus-reached-right-citynew-urban-agenda).

Although their development histories and contexts are distinct and they are at different stages of the urbanization continuum, yet PICs' urbanization-related issues demonstrate commonalities with those of larger developing countries (Jones, 2005). The key themes and ideas underscored in delineating this theoretical framework are therefore also instructive for addressing urban shelter issues of PICs and similar small island settings. 


\section{Development Challenges of Sids}

The United Nations today recognizes 57 SIDS spread across, mainly, the Indian and Pacific oceans and the Caribbean, Mediterranean, and South China seas. It was at the Earth Summit of 1992 in Rio-de-Janeiro when SIDS were first recognized as a distinct group of countries that face a unique set of developmental challenges. This number only denotes independent states or autonomous territories. Counting the small islands of larger archipelagic and continental developing nations, which share largely similar constraints and threats to development, raises this number dramatically - Indonesia itself has about 6000 inhabited small islands.

The factors that saddle development in many SIDS are often linked to their disadvantageous geography and/or exploitative colonial histories. Briguglio (1995) identified their small size, insularity, remoteness, and proneness to natural disasters as disadvantages that contribute to unusually high vulnerabilities. As research on various aspects of SIDS' development has grown lately, scholars have articulated other barriers to their economic growth-limited endowments of natural resources; low diversification of production (especially, manufacturing and producer services); strong dependence on exports and international trade; and high costs of transportation and communication (McGillivray et al., 2008). A related challenge, therefore, is that SIDS have a poorly developed private sector but an inflated public sector (UN-Habitat, 2015). Additionally, their small populations and inadequate infrastructure do not generate strong internal demand and economies of scale, rendering them unduly to external economic shocks. At the same time, growth and development in SIDS is strongly influenced by foreign direct investment (FDI) (Read, 2008) - United Nations data suggest that FDI accounts for over 70 percent of SIDS' GDP overall, and well over 100 percent in some (McGillivray et al. 2008, p. 482). Waves of globalization-first under colonialism and then neoliberalismembedded PICs into a global capitalist network (Firth, 2000). With globalization lately upping international labor migration (Read, 2004), both international migration and remittances now play a significant role in reducing poverty in developing countries (Adams \& Page, 2005; Brown \& Jimenez, 2008), more so but in SIDS and PICs (Connell \& Brown, 2005) where limited urban and little rural development make even domestic urban-rural remittances critical. To explain economic development in PICs, Bertram and Watters (1985) proposed the MIRAB model - the combined effects of migration, remittances, aid, and bureaucracy 'crowd out' export-oriented growth in these 'rentier' societies; however, others argue the MIRAB allusion that island economies exist in such a 'steady state' ignores weak governance structures that thwart export-oriented production and economic growth (Fraenkel, 2006). Governments of large archipelagic countries like the Philippines and Indonesia actively promote and regulate international labor migration (Lindquist, 2010, p. 199). Circular migration and remittances have long characterized symbiotic relationships in Indonesia between the rural and urban economies, and small and big islands (Firman, 1994; Hugo, 2000). To overcome their locational disadvantages and economic malaise, the World Bank has also strongly recommended more circular skilled and unskilled migration among PICs by 
lowering barriers to labor mobility (World Bank, 2009). Akin to its connection to globalization, migration also depends on and fuels expanding urbanization.

At 60 percent, SIDS' urbanization level is quite high but uneven (from 12 percent in Papua New Guinea to 100 in Nauru), and the threat of rising sea levels makes the issue exceedingly complex (UN-HABITAT, 2015). The mean urbanization rate of SIDS is a little below the global average of 1.7 percent, but the Pacific's 4.3 percent makes it the world's fastest urbanizing region, where periurbanization is happening at over 16 percent. Owing largely to colonization, between the 1850s and 1914, approximately, SIDS witnessed the first wave of globalization-induced urbanization (Firth, 2000). Large scale, brisk urbanization in SIDS is relatively recent, dating back to the 1960 s when new post-colonial island states began experiencing considerable migration, which accelerated from the 1980s as globalization intensified. Urbanization, globally, has raised gross domestic products (GDPs), but less so in SIDS, especially in PICs, which often have a large informal sector (UN-HABITAT, 2015, p. 14). Most SIDS also demonstrate urban primacy, whereby one urban center has disproportionately high concentrations of people, services, and economic opportunities (Connell \& Lea, 2002). Challenges of urbanization usually seen in fast developing non-island states - sprawl, dearer urban land, unaffordable housing, informal settlements, and environmental stressors-are growing in SIDS, especially where tourism is a strong economic driver (e.g. Maldives and the Caribbean states), (UN-HABITAT, 2015, pp. 15-16). In large archipelagic countries like Indonesia, too, urbanization is accelerating in smaller cities and on smaller islands, butweak infrastructure, services, and human resources means their economic growth lags substantially behind that of large metropolitan agglomerations (World Bank, 2012). Among many PICs, rural-urban migration and natural urban population growth continue to reinforce capital cities' urban primacy, while expanding slums, informal settlements, as well as formal ones catalyze periurbanization (Jones, 2007).

The potentially damaging impacts of urbanization, development, and climate change are more intertwined in SIDS, and intensified by the fragility of their ecosystems. Even in the Pacific and Caribbean island territories of the United States, continually increasing housing density and related development (rural to urban/exurban transformation), are estimated to impact 3 to 25 percent of each's forested lands (Stein et al., 2014). The institutional and resource capacitiesof SIDS areyet weaker than what managing the transformations from accelerating urbanization demands. Therefore, the impacts of ecological damage and climate change related extreme weather events will be significantly harsher on SIDS without sound shelter and services. Furthermore, the affordability of land and housing in PICs, especially, is projected to worsen with more globalization and tourism growth. Natural beauty is an abundant resource in most SIDS and, in some, other natural resources are also plentiful. Surging demand for Papua New Guinea's natural resources and globalization of the real estate sector mean thatforeign real estate investors and multinational companies are sharply driving up real estate prices in cities Port Moresby and Lau (http://www.century21global.com/papua-new-guinea). 
Tourism is one of the largest growing economic sectors worldwide, one that gives SIDS a natural competitive advantage; from 2000 to 2013 tourist arrivals in SIDS increased by 50 percent, and recent tourism growth has helped a few shed the least developed country (LDC) tag (UNWTO, 2014). Already, large shares of the GDP in PICs (about a third in Fiji, Samoa, Vanuatu, and in Palau almost 60 percent) come from tourism; but, even where it is a nascent industry, unique landscapes and cultural heritages make for abundant potential to develop tourism (Kronenberg \& Khor, 2016, p.8). Easing travel restrictions across and within regions, an expanding global hotel industry, falling costs of international air travel, and growing disposable incomes in emerging economies (especially, in Asia) are stoking unprecedented demand for travel to newer destinations. However, poor planning and management in SIDS can jeopardize the tourism industry's long-term sustainability, with wideranging socioeconomic implications.

Cautionary observers like Nowak \& Sahli, (2007) see in SIDS' rapid tourism growth the potential for a tourism-variant of Dutch disease-rapid expansion in a certain traded sector of an economy (mostly, natural resource related) starves other traded sectors. If global capital and demand can vigorously alter the tourism industry in SIDS, then it is essential to acknowledge that the attendant disruption of customary property regimes and weak land markets can cause significant accumulation through dispossession, and drive deeper the wedge of inequity in access to land and shelter. To this effect, Honolulu, the urban core of arguably the world's premier island tourism destination, is a sobering reminder. Colonial contact in the eighteenth century sowed the first seeds of tourism (Mak, 2015). Multiple phases of Hawaii'stransformation, starting with an agriculture boom to violent colonization to eventual incorporation as a state of the United States in 1959, tremendously boosted tourism and associated real estate development. Since the 1980s these have intensified on the coattails of globalization (Mak, 2008). Sustained tourism development transformed the state's economic fortunes but extensively altered traditional land management systems and practices, causing widespread dispossession through soaring land and housing prices (La Croix et al., 1995; La Croix, 2016).

Today, tourism and real estate, the two largest sectors of the economy make almost a third of Hawaii's GDP, and construction (5 percent) is the fourth largest (DBEDT, 2014). However, since statehood Hawaii's income inequality has steadily risen from 0.43 to 0.6 (Page \& Halliday, 2014), and Honolulu's housing affordability and homelessness crises are among the nation's worst and impact native Hawaiians and poor migrants the most (HACLEJ, 2014). In evaluating urbanization trends and impacts globally, a recent report underscores that the disconcerting trend of urban inequality is manifested and rooted in affordable housing options becoming ever scarcer (UN-HABITAT, 2016). It is urgent to recognize that shelter related problems do not just afflict advanced-economy island tourism centers like Honolulu. Such emerging challenges will accelerate in SIDS (with far weaker capacities than Honolulu's) as they court the globalized tourism industry for economic development. With 40 to 50 percent of the urban population already residing in squatter and informal settlements, especially in Melanesia, Jones (2012) portends that in the next decade such settlements will dominate housing provision and land 
development in PICs. Hence, adaptively and carefully adopting relevant planning innovations that have expanded shelter access in fast urbanizing contexts elsewhere can be instructive in addressing SIDS' compounding housing challenges. Generally speaking, these include tools that enable greater infill, denser, and more inclusive development (UN-HABITAT, 2015).

\section{RESULTS AND DISCUSSION}

\section{Shelter Challenges In Honolulu, Surabaya, And Dili}

This section highlights some shelter challenges in Honolulu, Surabaya, and Dili, as well as their causes and responses to them. These cities represent island societies at different stages of development, which means their problems and their degrees are quite distinct. One can consider them as embodying a continuum of development, with associated developmental challenges. The three have comparable populations, so discussing them makes sense. Honolulu is one of the most popular tourist destinations in the world. As tourism became its leading industry, it impacted its real estate sector; consequently, access to affordable housing has steadily worsened. Surabaya can be considered a mid-tier developing country city. Its economy has been growing steadily, and it is experiencing a brisk uptick in large real estate development. It is also widely regarded as a city that successfully effected citywide improvement in the shelter conditions of its poor neighborhoods through sustained urban upgrading (Das, 2017). However, following extensive decentralization and the surge in large development projects, it is now faced with new challenges to provide adequate and supportive dwelling environments for the poor. Dili, the capital of newly independent Timor Leste, is a city where development is beginning to happen after long periods of occupation and political violence. Its struggle to form institutions of planning and governance is typical of the challenges of poor SIDs with limited resources. The following paragraphs will highlight specific aspects and issues, in each city, relevant to development and theirimpacts on the shelter sector.

\section{Honolulu}

The history of Hawaii's development helps one understand Honolulu's current affordable housing challenges. This story of sustained and significant economic and demographic transformation, heavily influenced by both state and market forces, is instructive for poor or developing SIDS. It illustrates that without robust pro-poor policies and mechanisms in place, the pace of development and change can outstrip the capacity of even the wealthiest cities in developed societies/economies to address the challenge of affordable and adequate shelter for all. Intensifying urbanization and the simmering potential for globalization to quickly transform tourism and real estate development in SIDS lend this discussion a foreboding tone. 
Located on the island of Oahu, in the middle of the Pacific Ocean, Honolulu is the capital city of Hawaii [the $50^{\text {th }}$ state of the United State (US)], which comprises the Hawaiian archipelago. Honolulu is unique because it is at once the most isolated metropolitan region in the world as well as one of the most frequented tourist destinations anywhere. According to the 2010 US Census, the population of the Honolulu metropolitan area was over 390,000 (in 2017 it is estimated to be over 402,000 ), while the population of the island of Oahu, which also constitutes the City and County of Honolulu is a little under a million (http://worldpopulationreview.com/us-cities/honolulu-population/). In 2010 it was the $46^{\text {th }}$ largest city but the fourth densest urban region in the US. US Census records indicate that the decadal population growth was significant (fluctuating between 30 to 65 percent) after America's annexation of Hawaii as its territory in 1898 (it was an independent monarchy previously), up until statehood in 1959. In 1960 the population of Honolulu of Hawaii was over 294,000, and the decadal rate of population growth progressively declined until 1990 (0.1 percent; population over $365,000)$. Thereafter, the decadal rate of population increase began rising again [over 5 percent in 2000, and expected to be about 9 percent since 2010 (http://worldpopulationreview.com/us-cities/honolulu-population/). It is noteworthy that close to half of the population growth since 1960 has been on account of migration (from within and without the US) (Minerbi, 2011).

Following Captain James Cook's discovery of the Hawaiian islands in 1778, their agreeable climate and fertile lands spawned, since about the 1830s, flourishing whaling and agriculture industries (sugarcane, coffee, pineapple, and cattle rearing). In the late $19^{\text {th }}$ century, Hawaii's economy grew strongly on the backs of its sugar industry, which in the 1930s employed over 55,000 workers who were housed on the plantations (PBS, 2013). Speculators and investors from across the world descendedon Hawaii to try their luck. For several decades from the mid-19 ${ }^{\text {th }}$ century onward, scores of thousands of indentured laborers from China, Japan, Philippines, Korea, Puerto Rico as well as European workers were brought in (https://www.hawaii.edu/uhwo/clear/home/HawaiiLaborHistory.html). After Hawaii became a US territory, maritime trade between the US west coast and the far corners of the Pacific received a boost from numerous steamship lines, which also began bringing tourists (Mak, 2015). After statehood, the advent of jet travel to Honolulu grew tourism exponentially. In 1959 a quarter million tourists visited Hawaii (Mak 2008, 2015); by 1990 that number swelled to seven million annually, and now stands at over eight million (https://www.hvcb.org/corporate/history.htm; Mak, 2015).

Improved connectivity and increasing globalization fundamentally changed Hawaii's economy from being mainly agriculture-based to one driven by tourism and real estate development. Most of Hawaii's homegrown global agri-based industries, such as Dole's Hawaiian Pineapple company, all but shut down local operations by the 1990s as production shifted to cheaper developing world locations (Bartholomew, Hawkins \& Lopez, 2012). Another influence since statehood on the local economy has been the US military'sexpanding footprint. There are 11 military bases in Hawaii, mostly on Oahu; its almost 39,000 armed forces members constitute the fourth-largest military workforce in the nation (https://www.bizjournals.com/pacific/news/2012/09/17/oahu-has-fourth-largest- 
military-work.html); and, counting civilian workers makes the count soar past 101,000 (Hosek, Litovitz \& Resnick, 2011). Today, the biggest contributors to Hawaii's GDP, by percentage, are tourism (16.4), real estate rental and leasing (15.3), federal government (mostly military) (14.5), and state and local government (9.3), which account for the majority of the state's economy, followed by healthcare and social assistance (6.7), and construction (5.1) (Tian, 2014).

As tourism and real estate development grew and agriculture shrank, land and property prices escalated, and income inequality increased significantly. Today, among American cities, Honolulu's housing market isone of the most inert, expensive, and inaccessible. Foreign real estate investment in Honolulu and Hawaii exacerbated matters, especially since Aggressive Japanese investors in the mid1980s, when the US dollar had slid significantly, went on a buying frenzy, gobbling up homes and condominiums (up to 40 percent of all sales in some areas) as well as hotels, shopping malls, and other properties at exorbitant prices; home prices in some neighborhoods doubled in less than two years to well over a million dollars (Lindsey, 1988). That pace declined but the trend continued strongly, and in recent years it has intensified with a more diversified range of buyers who acquire properties for investment. Besides the Japanese, investors from inter alia Canada, Singapore, China, Hong Kong, Korea, Australia, and New Zealand are the biggest investors; yet, domestic capital now outdoes foreign investment (https://www.bizjournals.com/pacific/blog/morning_call/2015/02/japanese-lead-

foreign-investors-in-buying-hawaii.html). Having risen sharply since 2102, the median rent in Honolulu today is USD 2300 per month (https://www.zillow.com/honolulu-hi/home-values/), while the median home price is almost USD 744,000 and the median annual income USD 77,000, thereby making the cost of living in Honolulu about 47 percent higher than the national average (https://www.forbes.com/places/hi/honolulu/). Hawaii's income inequality (in terms of the income share of the top 1-percent)in 2012 was 13.36 percent;albeit the third lowest among all American states, it had more than doubled since 1978 (http://www.hawaiibusiness.com/hawaiis-growing-inequality-2/). Similarly, among American metropolitan areas, even though Honolulu has one of the lowest shares of low-income households (less than USD 50,0000 per annum) and the second lowest poverty rate (under 10 percent), the city also has the starkest concentrations of affluence and poverty (https://www.bizjournals.com/pacific/blog/morning_call/2014/01/income-inequalitylower-in-honolulu.html).

Given that the cost of living in Hawaii is the highest in the US, the above macro-trends have gradually contributed to a "wicked" affordable housing crisis. This, especially, affects some of the poorest groups such as Native Hawaiians and Micronesian migrants most adversely. In Hawaii, 87 percent of extremely lowincome families (earn less than 30 percent of the area median income or AMI) are extremely cost-burdened (i.e. they spend over 30 percent of the income on shelter); of these, almost 80 percentspend more than half of their income on rent; and, during 2005-12, the average rent increased by 45 percent but average income went up by 
just 21 (HACLEJ, 2014). Among Native Hawaiians, over half are renters; for 75 percent, the housing demand is below 120 percent of AMI; for 64 percent, below 80 percent of AMI; plus, overcrowding and multiple householdssharing a unit are common (SMS, 2016).

Despite various residential development projects and housing initiatives and incentives, the needs of the poorest in the state and the city remain unmet. For instance, despite a 2013 inclusionary zoning/housing (IZ) mandate [that requires new residential developments to include 10 percent of the units for households earning less than 80 percent of AMI, 10 percent for those in the 80-120 percent AMI bracket, and 10 percent for those below 140 percent of AMI], few affordable units had been built. Furthermore, progressive IZ regulations in several American cities reach down to the 60 percent (some even 40) AMI levels, but the few recent projects in Honolulu with IZ requirements, such as in the Kaka'ako mixed use redevelopment, only provide affordable units for the 120-140 percent AMI category (https://www.bizjournals.com/pacific/news/2017/03/01/hawaii-affordable-housingdevelopers-lenders-take.html).

After protracted and contentious deliberations involving multiple stakeholders, the City and County of Honolulu in March 2018 approved new IZ regulations based on Bill 58, which attempts to balance the demands of affordable housing advocates with developers' concerns (Friedheim, 2018). The new law eliminates the option for developers to pay in-lieu fees and not build affordable units. All new housing developments with over 10 units must produce affordable units at 120 percent $\mathrm{AMI} ;{ }^{1}$ if a developer only builds 5 percent for-sale units then they will remain affordable for 30 years, and if 15 percent are built then the affordability duration is relaxed to just five years. Over four out of five American cities with IZ policies mandate affordability restrictions for 30 years, and about one in three impose for 99 years. By comparison, with arguably the highest costs of living and income inequality, Honolulu's recent steps to increase the supply of affordable housing are feeble.

Two reasons often cited for the limited supply of affordable housing in Honolulu and the state are: 1) the exorbitantly high cost of land, supposedly also because 95 percent of the state's lands are zoned for conservation and agriculture; and 2) the Low Income Housing Tax Credit (LIHTC) program, a federal government program and the most common form of assistance for affordable housing developers, is insufficient to cover the high cost of land (Hollier, 2010). The Hawaii Public Housing Authority (HPHA) provides shelter to some of the poorest households through public housing units and rental assistance programs, such as the federal Section 8 housing voucher program, but such assistance is very limited. In 2016 the HPHA was managing less than 2400 vouchers and no new applications are being accepted (http://www.hpha.hawaii.gov/); while no new public housing units will be built in the foreseeable future, of the 6195 units the HPHA manages, over 400 are uninhabitable on account of lack of funds for repairs and maintenance (Hofschneider, 2015). The combined effects of these shelter challenges also causes

\footnotetext{
${ }^{1}$ Which corresponds to an individual with an annual income of $\$ 87,950$, or $\$ 125,560$ for a family of four.
} 
Hawaii to be the US state with the highest per capita rate of homelessness (487 per 100,000 , or over 2.5 times the national average), with Oahu hosting close to threequarters of this population (Bussewitz, 2015). Visitors to Honolulu are astounded upon seeing large concentrations of homeless people in temporary encampments around the city (see Figure 1). In 2014, in adding to a list of punitive regulatory measures to control public spaces, the city criminalized sitting or lying in many commercial and public areas, at all or certain times, by instituting a "sit-lie" ban, with plans to expand it further (Omaye, 2017). City officials and the police conduct regular "sweeps" (like evicting squatters and pavement dwellers in poor countries) to identify and penalize violators, almost all of whom are shelterless persons; stiff fines and possible incarceration inflict serious economic, physical, and psychological harm on this distressed sub-group of the poor population (DarrahOkike et al., 2018).

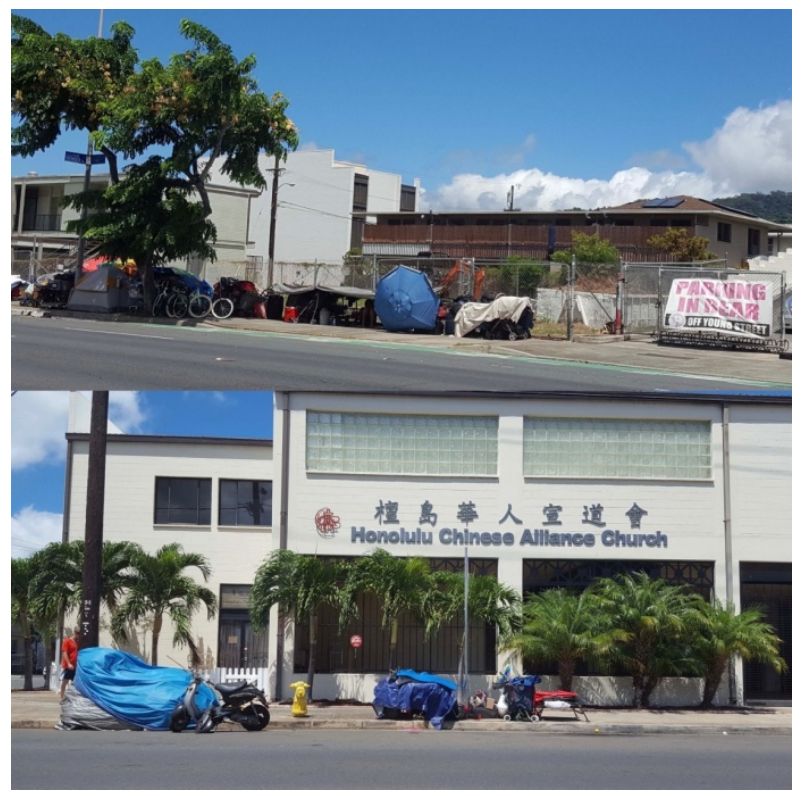

Figure 1. Homeless groups camping on Honolulu's streets Source: Author

\section{Surabaya}

Surabaya is Indonesia's second largest city with a population of under 3 million, 8 percent of which lives below the official poverty line (www.bps.go.id). The population of the city hardly changed over two decades since 2000 , but, by 2010 , Gerbangkertosusila, the metropolitan region of Surabaya comprising six surrounding regencies, had a population over 9 million. Located on the eastern edge of Java, this historic port city has long attracted traders, travelers, and migrants from far and wide (Dick, 2002). Dutch colonial rule established a powerful naval base 
here (Rimmer \& Dick, 2009). During President Suharto's authoritarian regime, the New Order (1965-1998), it transformed into an industrial city. Since the 1980s, both informal (including petty trade) and formal services, and the manufacturing industry have replaced agriculture as the main employers (Dick 2002; Peters, 2013). Several universities sprang up in Surabaya during the 1950s-60s and after the 80s; today, about 20 major universities and numerous polytechnics draw students from near and far.

Tunas \& Darmoyono (2014) classify the evolution of post-colonial Indonesian housing policy into three temporal phases: 1) from independence (1945) to the beginning of the New Order - a period of urban population explosion and state ambivalence toward squatters (Colombijn, 2011); 2) from the late-1960s to the fall of the New Order in 1998 - an era of aggressive, centralized upgrading efforts, the Kampung Improvement Programs (KIPs), pioneered in Jakarta and Surabaya; and 3) the post-decentralization period from 1999-when housing became a key responsibility of local and regional governments. Decentralization in 1999 helped Indonesia smoothly transition to democracy and its current political stability; yet, in upending cities' dependence on the central government (Lewis, 2010; Silver, 2005), decentralization also seems to have hurt shelter provision (Das, 2017).

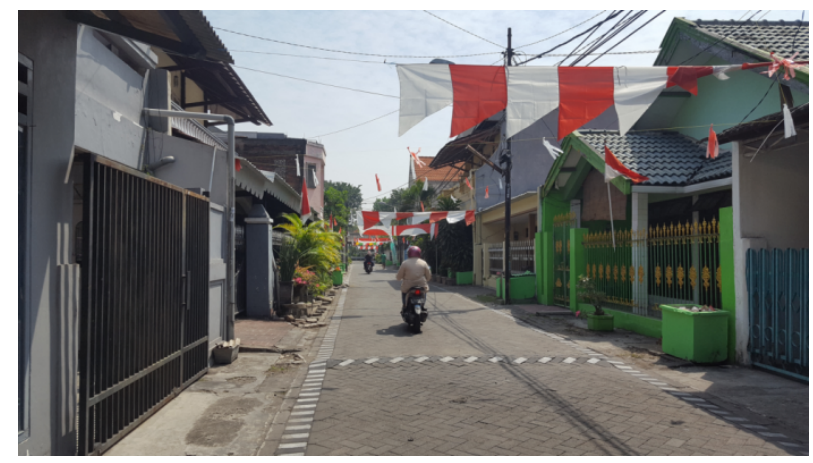

Figure 2. A typical formerly poor neighborhood in Surabaya upgraded through KIP Source: Author.

By pioneering KIP in 1969 and sustaining upgrading for four decades, Surabaya demonstrated that in situ upgrading was feasible at a citywide scale as an effective shelter option for the urban poor (Das, 2017). Surabaya's KIP success owed much to architect and educator Johan Silas (Das, 2016), whose vision and leadership helped to develop a unique synergy between the city government and a local university (ITS), especially its housing and settlements research center (Laboratorium Perumahan dan Permukiman, LPP). Between 1969 and 1999, international funding supported several KIPs, which increasingly leveraged community participation, to upgrade nearly all poor kampung in Surabaya (Figure 2). Decentralization motivated the city and LPP to autonomously launch a novel, citywide upgrading avatar called Comprehensive KIP (CKIP). Unprecedentedly community-led, each CKIP project devoted 70 percent of its budget to CBOoperated microfinance at the kelurahan level (akin to a municipal ward). However, 
for multiple reasons, CKIP (1999-2008) was far less extensive and effective than its KIP predecessors (Das 2015), but it established a firm template for community-led planning interventions at the kelurahan and neighborhood levels. Upgrading initiatives stopped with CKIP, but public housing (rental "walk-up" flats) efforts called rusunawa have since expanded. This reflects a challenge and a strategic local responseto decentralization under the current policy climate - cities might be happy to just pursue rusunawa as they just provide the land and the national government pays for everything else. Although rusunawa rents in Surabaya are among Indonesia's cheapest, the supply is scant-until 2016 only 13 such projects with about 3500 units had been completed or proposed (Das, 2016).

The exclusive city-LPP nexus has neglected NGOs as partners in shelter planning, which has hindered broad-based community capacity-building and empowerment of the weakest (Das, 2015b). The city and LPP discriminate against poor migrants without Surabaya residency and undocumented squatters by deeming them "ineligible" for state assistance (Several key informants, including the mayor of Surabaya, stated and defended this stance of the city during individual interviews the author conducted during August 2016 and July-August 2017). Consequently, neither has Surabaya ever considered squatter settlements along rivers, railway tracks, landfills, and other undesirable locations eligible for in situ upgrading; nor can poor migrants avail the affordable rusunawa (Das, 2016). A series of interviews that the author conducted with the city's mayor, planning officials, and experts on local development and planning revealed that while the city desires strong economic growth, it does not want any new industrial uses within the city limits because they attract potential squatters and informal sector workers; therefore, it wants its smaller neighboring jurisdictions to absorb new industries and provide affordable housing. The same respondents also believe that Surabaya's kampung will continue to provide affordable housing for the city's poor, both legal and illegal. The assumptions that urban growth can/should be regulated in such ways - especially, in a democratic, developing society - are questionable, and indicate an imperfect understanding of urbanization dynamics. Medium to large private sector development projects are proliferating. Since 2010, around the city center, over 50 new hotels (3-5 stars) have emerged (JLL, 2017), while hotel rooms have nearly tripled to about 15,000 (Salanto, 2017); and real estate prices have soared-the price of land along major commercial corridors, such as Jl. Mayjen Sungkono, is now around 60 million IDR (over 4600 USD) per square meter, almost 60 times of that in outlying areas (Interview with a senior official of the PT Ciputra, one of Indonesia's largest private developers, Surabaya, August 16, 2017). With neither concrete efforts to expand affordable housing nor specific building and planning guidelines for preserving Surabaya's kampung, the emergent trends of big development are likely to increasingly encroach upon the kampung and make shelter options for the poor scarcer and dearer. 


\section{Dili}

In making Dili the capital of Timor Leste in 1769, the Portuguese established one of the earliest, and few permanent European colonial outposts in Southeast Asia (ADB, 2012). After a protracted and bloody struggle for liberation from Indonesian occupation, which ensued just as centuries of Portuguese rule ended in 1975, Timor Leste finally became independent in 2002. However, internal tensions continued to cause civil strife, violence, and political instability, which led to the United Nations (UN) Security Council approving the deployment of international peacekeeping forces in 2006 under the banner of the UN Integrated Mission in Timor Leste (UNMIT). UNMIT helped in consolidating stability, enhancing a culture of democratic governance, and facilitating political dialogue among various Timorese stakeholders toward fostering national reconciliation and social cohesion (http://www.un.org/en/peacekeeping/missions/past/unmit/). Since 2008 the country has enjoyed its longest period of peace and political stability-including a successful transition of political power through a presidential election in 2015, and peaceful parliamentary elections in July 2017 (https://www.cia.gov/library/publications/the-world-factbookzz/geos/tt.html). A seemingly strong democratic ethos, a young population (half of the almost 1.3 million citizens are under 17 years old) ("Wake up and sell the coffee," 2017), and a reasonably high annual GDP per capita (USD 4200) are potential assets to augur robust development and growth; yet, the path to development involves significant developmental challenges, extant and emerging (The following paragraph highlights some of these challenges. Any claims/points without citations are based on the author's personal observations and conversations with multiple development experts during a short field visit to Dili, July 29-August 1, 2017).

Since 2004Timor Leste's economy has almost entirely relied on an oil and gas windfall. Besides petrodollars, the only other substantive source of revenue has come from growing coffee, which employs about a third of all households, but production has fallen by three-quarters since the colonial heyday ("Wake up and sell the coffee," 2017). It is the world's second most oil-dependent economy (oil revenues contribute 90 percent of the government's budget) (World Bank, 2013), and many observers fear an impending "resource curse" (Hooi, 2017) from the lack of diversification of the economy and because oil reserves will dry up in a few more years. The oil and gas sector's contribution to employment is negligible as the country has no refining/processing facilities. Within the last decade the government has hugely expanded social assistance spending, justifiably so, and created a strong social safety net; yet indicators related to human development, such as the population growth rate, poverty, malnutrition, hunger, and gainful employment, remain worrisome (World Bank, 2013). Among its chief impediments to brisk and effective development are inadequate and poor quality infrastructure and institutions. The acuteness of this shortcoming is apparent in the land management and shelter/housing sectors. Access to basic services like water and sanitation have improved much in recent years; nevertheless, in urban and rural areas alike, the level of services for the majority is far from being acceptable (Smets, 2015). 


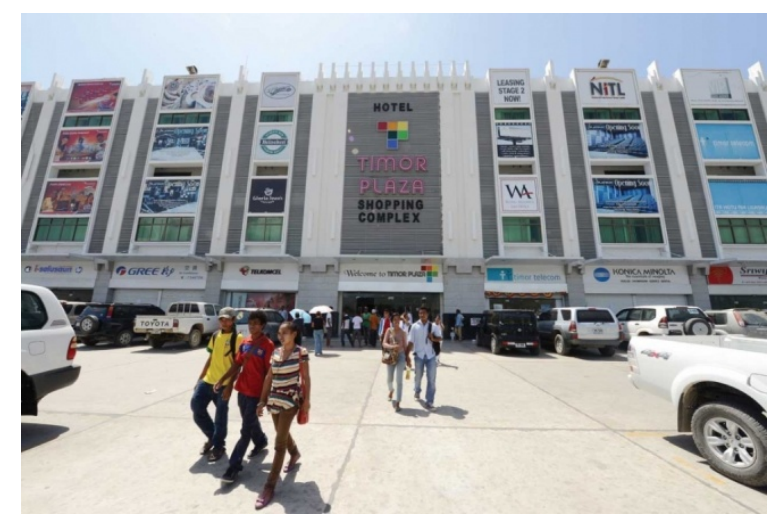

Figure 3. New urban development-Dili's first shopping mall Source: Author

The country is yet without a legal framework for property rights and land management. Almeida and Wassel (2016) view land-related conflict and dispossession as 'dormant giants' that threaten Timor Leste's security and stability (p.8). The widespread existence of customary land tenure systems, scattered and contested claims of formal land tenure granted under conflicting Portuguese and Indonesian regimes, extensive destruction of land records in the violence of 1999 , and weak state and civil society capacity all contribute to an ill-defined property rights system (Urresta \& Nixon, 2004; USAID, 2012). A draft land law tabled in 2012 is still being debated and unlikely to come into effect soon. It is feared that the criteria being proposed to recognize and establish land ownership claims will cause over a quarter of Dili's current population to be evicted without compensation (Almeida \& Wassel, 2017). Factors such as high rates of urbanization (of Dili's population, almost 40 percent moved in since 1999, and over 20 since 2008) and urban poverty; the onset of large development projects (Figure 3); an impending tourism boom - an official development policy objective of the government (Rajalingam, 2015); and the absence of a national housing policy could quickly worsen access to housing in cities such as Dili and Baucau. Near the northeast corner of Dili, new upscale resorts and residential complexes have appeared that cater to expat workers. While paved approach roads still do not reach some of these developments, yet 3 or 4 bedroom bungalows and townhouses commandmonthly rents of USD 3000-4000. This author learned that the owners of such developments are politically and/or financially powerful local elites close to the chiefs of villages (suku) or smaller communities (aldeia). Typically, land acquisition for such projects has been cheap, involving simple written agreements/approvals between the buyer and suku/aldeia leaders. However, witnessing the spoils from such development accrue to the new owners makes local residents feel swindled and disgruntled; incidents of stone-pelting at cars and homes in these new gated communities are not uncommon. 
UN-HABITAT and UNDP helped create a National Housing Policy that was adopted in 2007

(http://www.fukuoka.unhabitat.org/projects/timor_leste/detail01_en.html). The implementation of the policy has been weak. In 2011, the government's Millennium Development Goals (MDG) Suco Program, costing almost USD 90 million, appointed an Indonesian developer to build 9000 prefabricated homes. Implemented with little community involvement, the Suco Program failed on many fronts and hundreds of built homes remain vacant (Wallis \& Thu, 2013). However, some examples of simple but effective pro-poor interventions have also happened. UNHABITAT worked with the Ministry of Public Works on the City Upgrading Strategy (CUS) to undertake 12 pilot upgrading projects in four communities in Dili with just USD 30,000 (UN-HABITAT, 2006). Completed projects involved extensive community participation (not too common in Timor Leste), and instead of wholesale redevelopment and resettlement, it focused on smaller in situ improvements and security of tenure.

\section{Pro-Poor Shelter Policies and Planning for Sids/Pics}

The preceding sections discussed extant and emerging developmental challenges of SIDS, and postulated, using three representative cases, how shelter-related challenges may emerge and evolve as SIDS traverse a likely globalization-driven development trajectory. This section presents some innovative pro-poor shelter policy tools and planning interventions that have proven effective in different ways and to different degrees, in multiple developing and developed country contexts. This is not to suggest these are panaceas, but to emphasize that adapting one or more of these to their specific contextual conditions will enable SIDS, especially developing PICs, to prepare and meet better the shelter challenges that will accompany brisk urbanization and/or economic growth (Payne, 2001). Albeit their potential for broad applicability, the relevance of a particular intervention to a given context will depend on and have to be tailored to, inter alia, its level of economic development, nature and speed of urbanization, levels of poverty and informality, history of political economy, quality of state and market institutions, robustness of civil society, and the severity and urgency of threats from climate change. Nascent institutions and weak capacity of many SIDS/PICs mean that national regulatory frameworks for land management and property rights may not be immediately feasible or effective (Farvacque \& McAuslan, 1992); therefore, instead of top-down imposition, local adaptation of imported ideas to local institutions and practices is likely to be more fruitful. Table 1 summarizes these tools and approaches discussed ahead. 
Table 1. Potential interventions for pro-poor shelter policy in SIDS/PICs

\begin{tabular}{|c|c|c|}
\hline Policy tool & Contexts/programs (selected) & Advantages \\
\hline $\begin{array}{l}\text { Flexible/Alternative Tenure } \\
\text { Security, } \\
\text { Flexible/Incremental } \\
\text { Building Standards }\end{array}$ & $\begin{array}{l}\text { SNP (India), Baan Mankong } \\
\text { (Thailand), KIP (Indonesia), } \\
\text { Half houses (Chile) }\end{array}$ & Medium-term solutions \\
\hline $\begin{array}{l}\text { Participatory Slum } \\
\text { Upgrading }\end{array}$ & $\begin{array}{l}\text { KIP and CKIP (Indonesia), } \\
\text { SNP (India), OPP (Pakistan), } \\
\text { CMP (Philippines), Brazil }\end{array}$ & $\begin{array}{l}\text { Low-cost upgrading and } \\
\text { community empowerment }\end{array}$ \\
\hline Land Sharing & $\begin{array}{l}\text { Thailand, Pakistan, Indonesia, } \\
\text { Sri Lanka }\end{array}$ & $\begin{array}{l}\text { On squatted lands, for } \\
\text { housing and services } \\
\text { provision; mutually } \\
\text { beneficial for land owners } \\
\text { and others }\end{array}$ \\
\hline Land Pooling/Readjustment & $\begin{array}{l}\text { Japan, Taiwan, Korea, } \\
\text { Philippines, Ahmedabad } \\
\text { (India), Nepal, Indonesia, } \\
\text { Malaysia }\end{array}$ & $\begin{array}{l}\text { Managing peri-urbanization; } \\
\text { from haphazard to organized } \\
\text { planning; providing } \\
\text { improved services and } \\
\text { tenure }\end{array}$ \\
\hline $\begin{array}{l}\text { Nonprofit/Voluntary Sector } \\
\text { Housing Cooperatives }\end{array}$ & $\begin{array}{l}\text { Thailand, India, Sweden, USA, } \\
\text { UK }\end{array}$ & $\begin{array}{l}\text { Sustain affordable housing } \\
\text { for long, community- } \\
\text { managed, lower operating } \\
\text { costs }\end{array}$ \\
\hline $\begin{array}{l}\text { Community Land Trusts } \\
\text { (CLTs) }\end{array}$ & USA, England, Scotland & $\begin{array}{l}\text { Long-term leases; remove } \\
\text { cost of land from equation; } \\
\text { allow multiple uses }\end{array}$ \\
\hline $\begin{array}{l}\text { Land Value Capture; } \\
\text { Transfer of Development } \\
\text { Rights (TDRs) }\end{array}$ & $\begin{array}{l}\text { USA, Mumbai (India), Brazil, } \\
\text { Colombia }\end{array}$ & $\begin{array}{l}\text { Useful in high value/surging } \\
\text { markets; conservation; } \\
\text { sustainable peri-urban } \\
\text { development }\end{array}$ \\
\hline Inclusionary Zoning & $\begin{array}{l}\text { USA, Northern Europe, } \\
\text { Oceania, India, Indonesia (yet } \\
\text { weak) }\end{array}$ & $\begin{array}{l}\text { Steady supply of affordable } \\
\text { housing; social inclusion }\end{array}$ \\
\hline $\begin{array}{l}\text { Community Benefits } \\
\text { Agreement (CBA) }\end{array}$ & USA, UK, Canada & $\begin{array}{l}\text { Inclusive, equitable urban } \\
\text { development; preserving } \\
\text { affordable housing }\end{array}$ \\
\hline $\begin{array}{l}\text { Note: Abbreviations used } \\
\text { SNP (Slum Networking } \\
\text { Project) }\end{array}$ & & \\
\hline $\begin{array}{l}\text { KIP (Kampung } \\
\text { Improvement Program) }\end{array}$ & & \\
\hline $\begin{array}{l}\text { CKIP (Comprehensive } \\
\text { Kampung Improvement } \\
\text { Project) } \\
\text { OPP (Orangi Pilot Project) }\end{array}$ & & \\
\hline
\end{tabular}


Given scope and space limitations, the discussion of the ideas highlighted in this section is brief, since each idea lends itself to protracted discussion beyond the ambit of an ideas paper such as this one. The purpose here is to suggest - to planners, policymakers, and students of urbanizationin SIDS/PICs - a gist of various feasible interventions that could be customized for a particular context. Distinct permutations and combinations of multiple measures from this menu could suit a locale's idiosyncrasies.

\section{Flexible/alternative tenure security, and flexible/incremental building standards}

An inevitable attendant of urbanization in developing countries is the formation of slums and squatter settlements. Over the last fifty or so years, scholars' extensive field research and critical reflection have rightly pointed out that slums per se are not the 'problem' (Peattie, 1983); rather, it lies in urban policy and planning devising responses to slums based on reductive frameworks borrowed from the west, and flawed assumptions about urbanization dynamics, migration, urban informality, slum formation, livelihoods, the benefits of titling and homeownership, and how these impact the poor's housing constraints and choices (Payne, Durand-Lasserve \& Rakodi, 2009; Gulyani \& Talukdar, 2010; Peattie, 1994; Roy, 2005). The rigidity of the inherently dichotomous modern (western) property rights regime-individual freehold (ownership) or leasehold (rental) - fails to recognize the existence of other forms of tenure, especially pervasive and long-standing collective ones, and various categories of tenure that can be considered to lie on a continuum that allows, over time, progression from the so-called informal/illegal extremity to the fully legal freeholder end (Payne 2001). Just as dualistic urban policymaking fails to recognize this dynamism of tenure, it also is responsible for the arbitrariness and inflexibility of building standards - sizes, materials, forms, and construction techniques - that ratchet up the avoidable costs of shelter (Gulyani \& Connors, 2002; Peattie, 1987; Turner \& Fichter 1972).

Thus, SIDS and PICs that yet lack robust institutions for land management and shelter-delivery need to create ones that allow: a) context-appropriate, flexible forms of tenure, especially those that allow collective ownership, disaggregated land and structure ownership, as well as unconventional mixing of uses (e.g. agricultural, light industrial, commercial, and residential); and b) relaxed and flexible standards that allow for the incremental development of housing and flexible imposition of building standards. That incremental housing development with relaxed building standards can eventually attain quality and scalability as well as compatibility with the larger planning contexts has been demonstrated by architect and Pritzker-winner Alejandro Aravena's simple innovations in Chile and Mexico (https://www.nytimes.com/2016/05/23/t-magazine/pritzker-venice-biennale-chilearchitect-alejandro-aravena.html). Without altering the existing tenure structure, but by being flexible in providing basic services to squatter settlements, with assurances of non-eviction for 10 years, the Slum Networking Project (SNP) in Ahmedabad, India, allowed considerable improvements in shelter conditions (Das \& Takahashi, 2009). In Bangkok, the Baan Mankong program's flexible approach has facilitated 
various forms of land assembly and tenure arrangements to address poor squatter communities' myriad constraints (Das, 2016). Indonesia's renowned KIP efforts (Swanendri, 2002) are among the most successful urban upgrading programs anywhere. KIPs enabled housing improvements in kampung through self-help; consequently, the poor still have access to affordable housing, even in central locations of large cities. Interestingly, KIPs provided community-level services but did not support housing per se. In Surabaya, where KIPs likely were most successful, it was flexibility allowed in land use, tenure regulations, and building standards that let effective, quasi-informal housing markets thrive inkampung (Das, 2017). Likewise, recent investigations of previously criticized World Bank sites-andservices projects in India reveal that, over twenty-plus years, incremental housing development created thriving neighborhoods and valuable assets for owners, and provide affordable rentals (Gulyani, 2017).

\section{Participatory Slum Upgrading}

Following John Turner's clarion call denouncing slum eviction, beginning in the late 1960s, the notion of encouraging self-help housing gained popularity (Turner, 1968, 1976; Turner \& Fichter, 1972). Around that same time, successful in situ upgrading experiments in slum areas (kampung) in Indonesia (Silas, 1984) inspired the World Bank to internationally promote slum upgrading programs focused on providing basic services. Current wisdom holds the most effective pro-poor shelter intervention to be participatory slum upgrading (PSU) (Imparato \& Ruster, 2003; UN-HABITAT, 2010), which should allow communities and other stakeholders to participate; offer rights to land or tenure security; recognize the needs of renters; help sustain livelihoods; build social capital; and be citywide in scale (UNHABITAT, 2003). Since the 1980s the self-help idea had gradually weakened, yet scholars are again calling for reevaluating "assisted self-help" and prioritizing it in national and local housing policies (Bredenoord \& van Lindert, 2010), especially through PSU. Various innovative PSU have been successful in countries of South and Southeast Asia, Latin America, and Africa. The prime benefits of in situ slum upgrading are that it allows poor people access to affordable shelter and livable environments that also support livelihoods (or close to employment) as well as maintains their cultural networks, social capital, and safety nets built over time. Disrupting these by demolishing or even relocating to fringe areas has rarely proven effective; slums often reappear in central locations. Governments find PSU attractive for its low-cost interventions, and potential for cost recovery and greater efficiency (through participants' consensus and contribution of labor and finances), and program effectiveness (as participants influence planning and design choices). Additionally, CSOs and poor communities value the empowerment that emerges from PSU through engagement with the state in project planning, implementation, and maintenance. In SIDs and PICs, where state capacity to manage rapid urbanization and slum formation is likely to be weak, making PSU a shelter policy priority is prudent, even imperative. 


\section{Land Sharing}

Given squatting's ubiquity in many developing country cities, land sharing can be a viable solution (Badshah, 1996). It has proven effective in several countries, including Thailand, Pakistan, Philippines, and Indonesia. Most notably, Bangkok began utilizing land sharing in the 1980s to improve the living conditions of squatter communities (Angel \& Boonyabancha, 1988), and today it is a common and core intervention within its successful nationwide slum upgrading program, Baan Mankong (Das, 2018). Land sharing is a negotiated outcome that avoids the multitudinous deleterious consequences of slum clearance and eviction by striking a mutually beneficial compromise between the squatters and the land owner. Most commonly, it involves reconfiguring (rebuilding) the low-rise structures built by squatters into higher density, taller structures of multiple floors each. This returns a substantial part of the squatted land to the owner, which allows development for commercial gain. Despite the legal protection that private property enjoys, for various reasons, getting squatters to vacate lands, without resorting to inhumane means and violence, is often practically infeasible. Eyeing prospective benefits, the owner usually agrees to bear the majority of the expenses to be incurred in demolition, relocation, redesign, and redevelopment; negotiations among the involved parties and other stakeholders determine how costs and responsibilities are shared. Therefore, land sharing can be a rare 'win-win' solution because it: reduces the per-unit cost of providing services; maintains squatter communities' dignity, networks, and resources; is politically expedient for the government and less expensive (than serviced relocation to distant sites); and, for the owner, more profitable than if the land were unusable.

Although land sharing's effectiveness has long been acknowledged (Dowall \& Clarke, 1996), it has not been tried across many countries. This is because its feasibility and successful implementation require some favorable conditions (Badshah, 1996). Land sharing is more feasible where squatting is pervasive, the demand for land is high, and the threat of eviction is real and imminent. It is a process of tortuous and protracted negotiation that benefits from having certain institutional capacities and characteristics. First, and foremost, the local government and its agencies have to be willing to promote it and work together with squatter communities. That is rarely not a fraught process, and is especially trying in contexts where the state enjoys little trust among the poor. A squatter community should have the proclivity and capacity to mobilize itself, and form a capable $\mathrm{CBO}$ as its representative. The presence of able civil society intermediaries, such as experienced and resourceful NGOs, is usually instrumental in mobilizing, for empowering squatters, and mediating negotiations among stakeholders.

\section{Land Pooling/ Readjustment}

Land pooling/readjustment (LP/R) has long been practiced across the world, in different ways and for various purposes (Larsson, 1997)-from consolidating farmland and revitalizing inner cities to managing peri-urbanization and, lately, even 
post-disaster reconstruction (Hong \& Brain, 2012). LP/R was extensively used for modern urban development and revitalization in East Asia, especially in Japan, Korea, and Taiwan (Archer 1992; Sorensen 2000). The East Asian success of LP/R prompted its adoption in Indonesia, Malaysia, Thailand, Nepal, and India (Archer 1989; Karki 2004). The first part of LP/R involves "pooling" together different adjoining parcels of land owned by different landowners. The "readjustment" part then allows the reconfiguring of parcels as a purposeful, concerted effort to spatially redesign the layout of the consolidated land-for providing/upgrading infrastructure and services as well as for resolving issues of disputed occupation/claims (including squatting, as discussed above under land sharing). Trunk infrastructure such as roads, and amenities like sidewalks, parks, and other utilities/facilities can then be added or expanded in an effective manner. LP/R requires land owners to sacrifice a small portion of their lands, which then receive shared/public infrastructures. Landowners are fairly compensated, plus they benefit from improved infrastructure or tenurial status, and the associated rise in land values following improvements. LP/R is a discursive process requiring the consent of impacted landowners who eventually volunteer to part with a part of their property; thus, it is potentially less conflictriven than acquiring land forcibly (Farvacque \& McAuslan, 1992, pp.79-80). Progressive local governments that initiate LP/R can, wherever possible, routinely choose to set aside some land for building low-income housing (UN-HABITAT, 2008, p.28).

Ahmedabad, a large Indian city, has successfully leveraged LP/R, locally known as Town Planning Schemes (TPS), to acquire lands for expanding roads network, creating community facilities, and low-income housing, especially on the urban fringe (Ballaney, 2008; Mahadevia, 2018). However, implementing LP/R is not easy for it is a long and complicated process. Plus, it requires a good cadastral system, a legal framework that recognizes property rights and a sound judicial system that protects those, capacitated local planning agencies to undertake such endeavors, and even a culture of collaborative urban planning. Again, this brings to the forequestions of state-community trust and the mitigating/catalyzing role of CSOs. Moreover, without proper protective provisions, successful LP/R can also easily spur gentrification. Nevertheless, the voluntariness of landowner involvement and reduced costs to the public purse justify developing capacities to make LP/R realizable.

\section{Nonprofit Housing Cooperatives, and Community Land Trusts}

The aforementioned approaches and interventions, which require regulatory tweaking, presuppose a proactive state with adequate capacities (especially, when tinkering with land is involved). However, shelter related challenges are commonly attributed to wanting state capacity. The two options being discussed now-housing cooperatives and community land trusts (CLTs) - underscore a greater onus on the initiative of "non-state" stakeholders, from the nonprofit or voluntary sector. Studying housing cooperatives from Sweden, America, and India led Ganapati 
$(2009,2010)$ to stress that housing cooperatives are an important nonprofit sector contribution to fill the affordable housing gap left by public and private sector inadequacies. Although cooperatives first appeared between the two World Wars, they multiplied briskly only after the mid-1980s (albeit still insufficient), with neoliberal policy shifts causing the state to retract from producing housing, while the private sector remains increasingly unable or unmotivated to reach the lower income groups.

Successful cooperatives exemplify virtues of collective action. Collective ownership of land/property resists the pressures of speculative market forces bypreventing individual sales without collective approval. Ganapati (2010, p.368) suggests the existence of four types of housing cooperatives - tenure, rental, finance, and building. Aside from being able to produce and maintain affordable housing (state support may help or be indispensable), housing cooperatives extend other valuable benefits in developing countries-self-help construction, asset-building, building social capital, and empowerment through collective access to credit. Likewise, housing cooperatives can assume maintenance responsibilities of affordable public housing projects to reduce the state's shelter burden. Despite their desirability, housing cooperatives are not more commonplace because their thriving is incumbent upon the political economy of the context, and they face institutional constraints in capitalist economies. Nonprofit housing cooperatives tend to thrive and be effective when the overall nonprofit sector is robust, i.e. usually, where the state promotes and supports a free, diverse, and active civil society, yet grants it functional autonomy (Ganapati, 2010; Sen, 1999).

Somewhat similar to the cooperative, a new innovation fast gaining currency in the United States (also in the United Kingdom and Canada), to combat worsening housing inequality and affordability, is the community land trust (CLT) (Davis \& Jacobus, 2008). The concept's origin lies in traditional practices of collective ownership of common property resources. Some of the first CLTs sought to protect farmland and natural resources from development pressures; more recently, the principle has been adopted for protecting affordable housing stocks in cities. A registered nonprofit entity, the CLT is essentially a CBO created for community-led stewardship of land. With about 250 CLTs today, America's growing CLT movement (www.cltnetwork.org) seeks to remove land from the speculative real estate market and hold it in trust for the benefit of a collective. The aims are to: provide access to land and housing to those without; increase long-term community control of neighborhood resources; empower residents through their participation; and preserve the affordability of housing, permanently (UN-HABITAT, 2012, p.5). The CLT acquires permanent ownership of the land, and instead of selling units/plots to individual homeowners it grants them renewable long-term leases (usually, 99-year). From any subsequent sale, a homeowner receives only a fraction of the increase in property value; the CLT retains the rest for reinvesting and preserving affordability. In SIDS and PICs without adequate state capacity for providing affordable housing, CLTs could sustain long-term housing affordability after land is secured through state, community, or private (philanthropic) efforts. 


\section{Land Value Capture, and Transfer of Development Rights}

Land value capture (LVC) and the sale and/or transfer of development rights (TDRs) are two innovative land management tools, which aim for equitable urban development by focusing policy on private sector actors. Rapid urbanization makes cities in the developing world constantly struggle to provide well-serviced land with supporting infrastructures. But when cities do so or upgrade public infrastructure (usually in relatively affluent areas or central business districts), it commonly sends land values soaring, often then leading to gentrification, unequal development, and other speculative inducements (Mathur \& Smith, 2013; Smolka, 2013). Likewise, rezoning rural land for urban uses witnesses an 'urban multiplier' effect that swiftly increases land values manifold. Whereas such land value increments are impossible without public effort-infrastructure investments, administrative actions, and/or regulatory reform, etc.- the enjoyment of those increments is strictly privatized, benefiting only landowners in the impacted area. The concept of LVC is quite simple - to retrieve the part of land value increments due to public investments and utilize it for the broader public good (Smolka, 2013). Decentralized local governments (e.g. Brazilian and Colombian cities) can use LVC monies for funding infrastructure and services, including publicly built or funded affordable housing. Lately, Rajkot, a city in India, even funded new public transit infrastructure, ex ante, based on projected gains, using a combination of LVC, and sale of development rights, i.e. density bonuses (by letting more than the allowable built-up area, measured as the floor area ratio or FAR) (Mathur, 2015).

A commonly held notion, even among most urban planners and policymakers, is that development rights, which land ownership brings, are inseparably tied to the land in question, and thus fixed in space; yet, over time, land ownership in America came to be legally seen as comprising a 'bundle' of rights that could be treated differently (Mathur, 2015, p.235). Their unbundling allowed for development rights to be transferred from one site (sending) to another (receiving) as TDRs. Efforts to restrict development in certain areas for, say, environmental conservation or historical preservation typically create sending sites, whereas receiving sites are generated in areas where new development or densification is desired. Of course, this does not always materialize as desired, and, like in Taipei, it can instead abet uneven development (Shih \& Chang, 2016). In the 1990s, Mumbai pioneered the use of TDRs for slum redevelopment - to replace slums with high-rise, low-cost flats for slum dwellers (Mukhija, 2016). To get them to work with slum communities and NGOs in redevelopment projects, which resembled land sharing and redevelopment, private developers were also enticed with density bonuses and TDRs (Mukhija, 2003). The success in involving private developers in building housing for the poor was unprecedented; in particular, private developers made a beeline since TDRs were also made a tradable commodity. An important caveat is that such market-based tools can thrive only in extremely hot property markets, and also where planning and civil society institutions are well evolved. Nevertheless, in Mumbai too, TDRs yielded uneven development, congestion, and other undesirable 
consequences (Sanyal \& Mukhija, 2001; https://www.hdfc.com/blog/transferabledevelopment-rights-tdr-concept).

\section{Inclusionary Zoning}

Inclusionary zoning (IZ) or inclusionary housing is another American planning innovation of the 1970s that aims to increase affordable housing production by imposing conditions on private developers (for a comprehensive assessment of IZ, see Mukhija, Das, Regus \& Slovin Tsay, 2015). IZ generally requires private developers to set aside a specific portion (usually 10-15\%) of units in all market-rate housing developments as affordable units (A city establishes its affordability criteria in terms of the median income (AMI). Typical IZ affordability limits lie within the 40-140 percent of AMI range, depending on how expensive a market and/or how pro-poor a city is.). But IZ policies can be voluntary or mandatory, and offer both 'carrot' and 'stick' incentives (Table 2). IZ's limitation is that in expensive land and housing markets of rich societies it cannot deliver housing for the poorest.

Table 2. Types and elements of IZ programs

\begin{tabular}{ll}
\hline Type & Elements \\
\hline \multirow{2}{*}{ Type } & Voluntary \\
& Mandatory \\
Scope & Citywide/Geographically-defined \\
& All projects/Project type-defined (including, project \\
& size thresholds) \\
Affordable Housing & Set-aside percentages \\
& Targeted by income groups of beneficiaries \\
& Affordability terms \\
Cost-Offsets and & Density bonuses \\
Incentives & Zoning and design flexibility \\
& Expedited approvals \\
& Fee-waivers, reductions, deferrals \\
& Subsidies for affordable units \\
In-Lieu Alternatives & In-lieu fees \\
& Off-site construction or land dedication \\
\hline & Source: Adapted from Mukhija et al. (2015)
\end{tabular}

IZ remains a contested policy, criticized for it is believed to stifle market supply. However, growing research evidence and the steady rise of IZ, both across American cities and other developed countries (Calavita \& Malatch, 2010), increasingly vindicate its utility in expensive markets or where housing inequality is grim (Jacobus, 2015). Despite housing researchers calling for it, developing countries have not yet widely or vigorously adopted IZ policies. Indonesia, for instance, has had since the early 1990s a nationally mandated IZ regulation called the Hunian Berimbang (1:2:4). Yet, its implementation has been negligible because developers and local governments, too, find its elements incompatible with local 
conditions; plus, it only applies to the development of single-family homes, not multi-family apartments. Yet, IZ has the potential to be a vital part of the affordable housing solution for developing cities wherethe real estate sector is growing. With simple or flexible building standards, incremental development and/or self-help, the cost of housing the poorest in SIDS and PICs need not be unaffordable.

\section{Community Benefits Agreement}

In recent times, urban income inequality, especially in large American cities with high economic growth and/or poverty, has significantly worsened-Honolulu's is among the worst (Berube, 2018). Various factors - such as globalization induced deindustrialization, neoliberal policies, and increasing corporate interest in urban redevelopment - are responsible for the disproportionate disadvantaging of poor and marginalized groups. Also, in response, the last two decades have witnessed the emergence and spread of the community benefit agreement (CBA) as a tool for economic justice that redistributes a part of the spoils of development (Parks \& Warren, 2009). A CBA pushes development to be socially responsible. CBAs are legally binding, project-specific agreements between a private developer or state entity and a coalition of, say, CBOs, labor unions, and environmental or other advocacy groups. In America's democratized local planning structure, wherein community approval strongly matters for realizing local development plans, a CBA allows demanding tangible benefits such as local employment generation with living wage jobs, providing community amenities, affordable housing, child care, etc. As the new concept matures, there is growing concern about making CBAs inclusive and accountable (Gross, 2007).

CBAs, therefore, can be particularly salient in rapidly urbanizing and transforming SIDS and PICs. However, planning in such contexts is likely not yet a sufficiently democratic endeavor, and nor is civil society strong enough. To expect poor communities, therefore, to be able to negotiate or pursue CBAs on their own is unrealistic. Instead, local planners and planning institutions should advocate for institutionalizing CBAs as part of the development process, just as it is the responsibility of the larger state to grow and strengthen civil society institutions. With the necessary nurturing conditions in place, CBAs could make development more inclusive, equitable, and sustainable.

\section{CONCLUSIONS}

This paper outlined shelter and related challenges that SIDS and PICs are facing or possibly encounter as pressures from rapid urbanization and increasing migration driven by globalization, neoliberalism, and climate change keep mounting. It reviewed the literature on these areas of research to provide a theoretical framework to analyze the challenges. It argues that because of their unique geographical, economic, and developmental constraints, as well as potentials for tourism and real 
estate related growth (for being relatively exotic destinations), low-income SIDS and most PICs are likelyprone to follow a probable development continuum as their economies transform. Three cases-Honolulu, Surabaya, and Dili-exemplify the stages of this continuum. Whereas the shelter challenges for cities like Dili, in less developed SIDS, are plainly visible, even rich cities like Honolulu are saddled with unyielding challenges of urban inequality, especially in regard to shelter. The section that describes the shelter complexities and responses of the three individual cases illuminates essential differences that stem from the presence or absence of appropriate policies and governance structures.

Honolulu exemplifies how rapid urban development-spurred by a combination of tourism development, sudden surge in foreign demand and capital flows into the local real estate market, and lackof a concerted focus on affordable housing - has yielded an undesirable and avoidable situation of housing inequity. A recently introduced inclusionary zoning policy is laudable, but, unlike other American cities, it has been slow in coming and does not actually benefit the poor. Moreover, given the scale and size of the affordability gap, by itself, this IZ policy will be inadequate. It is encouraging, nevertheless, that affordable housing is now a vigorously debated policy topic, led by local nonprofits and policymakers.

Surabaya, as a fast developing but haphazardly urbanizing city in the late 1960s, which was experiencing growing internal migration, decided to implement systematic citywide slum upgrading (KIP) in its kampung or poor neighborhoods, and allow incremental housing development with flexible building and planning regulations. As other cities continued todemolishsquatter settlements orrelocate slums, Surabaya's KIP became a paragon of in situ upgrading, internationally. Sustaining it continuously with public support for over thirty years has helped to preserve, until now, affordable housing options for the poor in the central city. However, since decentralization in 1998, owing to competing priorities with limited resources, slum upgrading has gradually halted and the city's pro-poor shelter actions have weakened. Furthermore, the rising demand for large real estate development increasingly threatens the viability of the kampung to remain the poor's haven.

Despite its uniquely scarred history of prolonged foreign occupation, Dili is still representative of many island cities in PICs. Necessary institutions of planning and land management are at best inchoate, if not nonexistent. The stable transition to democracy and nascent efforts at institution building are promising. It remains to be seen how well a new property rights regime and land law being developed will uphold the customary land rights that are pervasive and characteristic of Timorese society. Land values have soared as demand for serviced land and housing grows from demand generated by expatriate workers, tourism development, and a hydrocarbons boom. Even as migration to cities intensifies, slum formation and evictions are on the rise. Culturally sensitive property rights to balance modern demands, appropriate planning tools to provide affordable housing, CSOs that advocate land and housing rights, and training cadres of skilled planners are all needed, urgently.

The responses to dealing with urbanization and shelter challenges are indeed contextual, strongly influenced by a locale's developmental history and extant 
political economy. An earlier section gleaned effective shelter related policy responses, and innovative programs and tools from developing and developed countries. Overall, these mainly focus on lowering development and construction costs, tweaking land management policies, redistributing profits of development aided by public investments, and greater engagement of civil society for alternative institutional arrangements. It is neither possible nor prudent to proffer specific solutions as shelter panaceas for SIDS and PICs. However, it is hoped that the discussion clarifies - for planners, policymakers, students, social activists, housing advocates, and CSOs - the potential for the contextualized adaptation of these ideas. Likewise, in most less developed and developing locales, it is likely that only some mix of these ideas will prove useful. Furthermore, even cities like Honolulu, with capable institutions and robust economies, could benefit from adapting interventions attempted in settings with weaker institutions and capacities to explore new ways of making shelter more accessible and affordable. As emphasized in the New Urban Agenda (United Nations, 2017), for developing countriesslum upgrading is a salient intervention; but its applicability in the developed world is negligible. Yet, the potential to adapt other ideas-land pooling and readjustment, nonprofit cooperatives and community land trusts, land value capture and transfer of development rights, inclusionary zoning, and community based agreements-is universal.

Most of the ideas and interventions for improving shelter affordability and accessibility are neither too novel nor esoteric for urban planners. Yet, in most places, their adoption and implementation are hampered and their scaling-up is rarely facile. This is truer, and acknowledged, in the case of less developed contexts where the capacity of state institutions is constrained. Often, another lacuna is the absence of a robust civil society or the reluctance or unfamiliarity of state institutions to work with CSOs. But, for durable and effective interventions, statecivil society collaboration is indispensable. Thus, in addition to strengthening the technical, financial, cadastral, and human resource capabilities of its state institutions, SIDS and PICs should emphasize enabling a strong nonprofit sector to partner with the state in their quest for affordable and sustainable shelter for all. Research on institutions involved in planning in developing countries is constantly expanding, but little exists, as I have argued elsewhere (Das \& Luthfi, 2017), on how the nature of planning educationaffects the cultures, values, approaches, prejudices, and efficacies of planners and planning institutions. Successfully realizing good shelter ideas on the ground, after all, will require those who not only appreciate them, but can also critically evaluate, smartly adapt, and earnestly execute them. The urbanization and shelter challenges SIDs and PICs face are tall, but the possibility to address them by combining various proven options does not leave them insurmountable. 


\section{REFERENCES}

Adams, R. H., \& Page, J. (2005). Do international migration and remittances reduce poverty in developing countries? World Development, 33(10), 1645-1669.

ADB. (2012). The State of Pacific Towns and Cities: Urbanization in ADB's Pacific Developing Member Countries. Mandaluyong City, Philippines: Asian Development Bank. Retrieved from http://www.adb.org/publications/statepacific-towns-and-cities-urbanization-adbs-pacific-developing-membercountries

Almeida, B., \& Wassel, T. (2016). Survey on Access to Land, Tenure Security and Land Conflicts in Timor-Leste. San Francisco: The Asia Foundation \& Van Vollenhoven Institute for Law. Retrieved from http://asiafoundation.org/publication/survey-access-land-tenure-security-landconflicts-timor-leste/

Archer, R. W. (1989). Transferring the urban land pooling/readjustment technique to the developing countries of Asia. Third World Planning Review, 11(3), 307.

Archer, R. W. (1992). Introducing the Urban Land Pooling/Readjustment Technique into Thailand to Improve Urban Development and Land Supply. Public Administration \& Development, 12(2), 155-174.

Badshah, A. (1996). Our urban future: new paradigms for equity and sustainability. London; Atlantic Highlands, NJ: Zed Books Ltd.

Ballaney, S. (2008). The town planning mechanism in Gujarat, India. Washington, D.C.: World Bank Institute.

Bartholomew, D. P., Hawkins, R. A., \& Lopez, J. A. (2012). Hawaii Pineapple: The Rise and Fall of an Industry. HortScience, 47(10), 1390-1398.

Beall, J., \& Fox, S. (2006). Urban Poverty and Development in the 21st Century: Towards an Inclusive and Sustainable World (Oxfam Research Report). Oxfam GB.

Beard, V. A., Miraftab, F., \& Silver, C. (Eds.). (2008). Planning and decentralization: contested spaces for public action in the global south. London; New York: Routledge.

Bertram, G., \& Watters, R. F. (1986). The MIRAB process: Earlier analyses in context. Pacific Viewpoint, 27(1), 47-59.

Berube, A. (2018). City and metropolitan income inequality data reveal ups and downs through 2016. Washington, DC: The Brookings Institution.

Bredenoord, J., \& van Lindert, P. (2010). Pro-poor housing policies: Rethinking the potential of assisted self-help housing. Habitat International, 34(3), 278-287. https://doi.org/10.1016/j.habitatint.2009.12.001

Brenner, N., \& Theodore, N. (2002). Cities and the Geographies of "Actually Existing Neoliberalism." Antipode, 34(3), 349-379. https://doi.org/10.1111/1467-8330.00246

Briguglio, L. (1995). Small island developing states and their economic vulnerabilities. World Development, 23(9), 1615-1632. https://doi.org/10.1016/0305-750X(95)00065-K

Brown, R. P. C., \& Jimenez, E. (2008). Estimating the net effects of migration and remittances on poverty and inequality: comparison of Fiji and Tonga. Journal 
Das: DEVELOPMENT AND SHELTER CHALLENGES OF SMALL ISLANDS: PLANNING WITH A PROPOOR PERSPECTIVE
of International
Development,
20(4),
$547-571$.

https://doi.org/10.1002/jid.1474

Buckley, R. M., \& Kalarickal, J. (2005). Housing Policy in Developing Countries: Conjectures and Refutations. The World Bank Research Observer, 20(2), 233257. https://doi.org/10.1093/wbro/lki007

Bussewitz, C. (2015, November 9). Homelessness in Hawaii grows, defying image of paradise. Huffington Post . Retrieved http://www.huffingtonpost.com/entry/homelessness-hawaiigrows us 563f604ee4b0307f2cadc628\#comments

Calavita, N., \& Mallach, A. (Eds.). (2010). Inclusionary housing in international perspective: affordable housing, social inclusion, and land value recapture. Cambridge, MA: Lincoln Institute of Land Policy.

Chakrabarty, A. (2017). Affordable Housing and Ethiopia's War on Poverty. Economic \& Political Weekly, 52(4). Retrieved from http://www.epw.in/journal/2017/4/perspectives/affordable-housing-andethiopias-war-poverty.html

Colombijn, F. (2011). Public housing in post-colonial Indonesia: The revolution of rising expectations. Bijdragen Tot de Taal-, Land-En Volkenkunde / Journal of the Humanities and Social Sciences of Southeast Asia, 167(4), 437-458. https://doi.org/10.1163/22134379-90003579

Connell, J., \& Brown, R. P. (2005). Remittances in the Pacific: an overview (Pacific Studies Series). Manila, Philippines: Asian Development Bank. Retrieved from https://think-asia.org/handle/11540/2660

Connell, J., \& Lea, J. (2002). Urbanisation in the Island Pacific: Towards sustainable development. London and New York: Routledge.

Dahiya, B. (2012). Cities in Asia, 2012: Demographics, economics, poverty, environment and governance. Cities, 29, Supplement 2(0), S44-S61. https://doi.org/10.1016/j.cities.2012.06.013

Dahiya, B. (2014). Southeast Asia and Sustainable Urbanization. Global Asia, 9(3), 84-91.

Darrah-Okike, J., Soakai, S., Nakaoka, S., Dunson-Strane, T., \& Umemoto, K. (2018). "It Was Like I Lost Everything": The Harmful Impacts of HomelessTargeted Policies. Housing Policy Debate, 0(0), 1-17. https://doi.org/10.1080/10511482.2018.1424723

Das, A. (2015a). Autonomous but constrained: CBOs and urban upgrading in Indonesia. Cities, 48, 8-20. https://doi.org/10.1016/j.cities.2015.05.009

Das, A. (2015b). Slum upgrading with community-managed microfinance: Towards progressive planning in Indonesia. Habitat International, 47, 256-266. https://doi.org/10.1016/j.habitatint.2015.01.004

Das, A. (2016). Is innovative also effective? A critique of pro-poor shelter in SouthEast Asia. International Journal of Housing Policy, 1-33.

Das, A. (2017). A City of Two Tales: Shelter and Migrants in Surabaya. Environment and Urbanization ASIA, $8(1), \quad 1-21$. https://doi.org/10.1177/0975425316686501 
Das, A., \& Luthfi, A. (2017). Disaster Risk Reduction in Post-Decentralisation Indonesia: Institutional Arrangements and Changes. In R. Djalante, M. Garschagen, F. Thomalla, \& R. Shaw (Eds.), Disaster Risk Reduction in Indonesia (pp. 85-125). Cham, Switzerland: Springer International Publishing. https://doi.org/10.1007/978-3-319-54466-3_4

Davis, J. E., \& Jacobus, R. (2008). The City-CLT Partnership: Municipal Support for Community Land Trusts (Policy Focus Report No. PF017). Cambridge, MA: Lincoln Institute of Land Policy. Retrieved from http:/www.lincolninst.edu/publications/policy-focus-reports/city-cltpartnership

Davis, M. (2007). Planet of slums (Paperback ed). London; New York: Verso.

de Soto, H. (1989). The other path: the economic answer to terrorism. New York, NY: Basic Books.

de Soto, H. (2000). The mystery of capital: why capitalism triumphs in the West and fails everywhere else. New York: Basic Books.

Deshingkar, P. (2006). Internal migration, poverty and development in Asia: Including the excluded. IDS Bulletin, 37(3), 88-100.

Dick, H. W. (2002). Surabaya, city of work: a socioeconomic history, 1900-2000. Athens, OH: Ohio University Press.

Dowall, D. E., \& Clarke, G. (1996). A framework for reforming urban land policies in developing countries (Policy Paper No. 7). Washington, D.C.: The World Bank.

Farvacque, C., \& McAuslan, P. (1992). Reforming Urban Land Policies and Institutions in Developing Countries (Policy Paper No. 5). Washington, D.C.: The World Bank.

Ferguson, B., \& Smets, P. (2010). Finance for incremental housing; current status and prospects for expansion. Habitat International, 34(3), 288-298. https://doi.org/10.1016/j.habitatint.2009.11.008

Firman, T. (1994). Labour Allocation, Mobility, and Remittances in Rural Households: A Case from Central Java, Indonesia. Sojourn: Journal of Social Issues in Southeast Asia, 9(1), 81-101.

Firth, S. (2000). The Pacific Islands and the globalization agenda. The Contemporary Pacific, 12(1), 178-192.

Fraenkel, J. (2006). Beyond MIRAB: Do aid and remittances crowd out export growth in Pacific microeconomies? Asia Pacific Viewpoint, 47(1), 15-30. https://doi.org/10.1111/j.1467-8373.2006.00300.x

Friedheim, N. (2018, March 27). New Honolulu Housing Bill Seeks the Middle Ground. Honolulu Civil Beat. Retrieved from http://www.civilbeat.org/2018/03/updated-honolulu-housing-bill-seeks-themiddle-ground/

Friedmann, J. (2011). Becoming urban: periurban dynamics in Vietnam and Chinaintroduction. Pacific Affairs, 84(3), 425-434.

Ganapati, S. (2009). Enabling the voluntary sector in Third World Housing. Cityscape, 11(1), 33-51. 
Das: DEVELOPMENT AND SHELTER CHALLENGES OF SMALL ISLANDS: PLANNING WITH A PROPOOR PERSPECTIVE

Ganapati, S. (2010). Enabling Housing Cooperatives: Policy Lessons from Sweden, India and the United States. International Journal of Urban and Regional Research, 34(2), 365-380. https://doi.org/10.1111/j.1468-2427.2010.00906.x

Gilbert, A. (1997). On subsidies and home-ownership: Colombian housing policy during the 1990s. Third World Planning Review, 19(1), 51.

Glaeser, E. L. (2012). Triumph of the city: how our greatest invention makes us richer, smarter, greener, healthier, and happier. New York, NY: Penguin Books.

Goldfinch, S. (2015). Property rights and the mystery of capital: A review of de Soto's simplistic solution to development. Progress in Development Studies, 15(1), 87-96. https://doi.org/10.1177/1464993414546971

Griffin, K. (2003). Economic globalization and institutions of global governance. Development and Change, 34(5), 789-808.

Grindle, M. (2012). Good governance: the inflation of an idea. In B. Sanyal, L. J. Vale, \& C. D. Rosan (Eds.), Planning ideas that matter: livability, territoriality, governance, and reflective practice (pp. 259-282). Cambridge, MA: MIT Press.

Gross, J. (2007). Community Benefits Agreements: Definitions, Values, and Legal Enforceability. Journal of Affordable Housing \& Community Development Law, 17(1/2), 35-58.

Gulyani, S., \& Talukdar, D. (2010). Inside Informality: The Links Between Poverty, Microenterprises, and Living Conditions in Nairobi's Slums. World Development, $38(12)$, https://doi.org/10.1016/j.worlddev.2010.06.013

HACLEJ. (2014). Hawai'i's Affordable Housing Crisis. Honolulu, HI: Hawai'i Appleseed Center for Law and Economic Justice (HACLEJ).

Harris, R., \& Giles, C. (2003). A mixed message: the agents and forms of international housing policy, 1945-1973. Habitat International, 27(2), 167191. https://doi.org/10.1016/S0197-3975(02)00044-9

Harvey, D. (2001). Globalization and the spatial fix. Geographische Revue, 2(3), 23-31.

Hofschneider, A. (2015, November 25). How Crappy Sewers Make It Hard To Build Housing In Honolulu. Civil Beat. Retrieved from https://www.civilbeat.org/2015/11/how-crappy-sewers-make-it-hard-to-buildhousing-in-honolulu/

Hollier, D. (2010, October). The High Cost of Affordable Housing. Hawaii Business Magazine. Retrieved from http://www.hawaiibusiness.com/the-high-cost-ofaffordable-housing/

Hong, Y.-H., \& Brain, I. (2012). Land readjustment for urban development and postdisaster reconstruction. Land Lines, 24(1).

Hooi, K. Y. (2017, July 25). After Timor-Leste's Election, a Young Democracy Looks Forward. The Diplomat. Retrieved from http://thediplomat.com/2017/07/after-timor-lestes-election-a-youngdemocracy-looks-forward/ 
Horn, A. (2014). Urban Growth Management Best Practices: Towards Implications for the Developing World. International Planning Studies, 0(0), 1-15. https://doi.org/10.1080/13563475.2014.942513

Hosek, J., Litovitz, A., \& Resnick, A. C. (2011). How Much Does Military Spending Add to Hawaii's Economy? (Technical Report). Santa monica, CA: Rand Corporation.

Retrieved

from

https://www.rand.org/pubs/technical reports/TR996.html

Hugo, G. (2000). The Impact of the Crisis on Internal Population Movement in Indonesia. Bulletin of Indonesian Economic Studies, 36(2), 115-138. https://doi.org/10.1080/00074910012331338913

Imparato, I., \& Ruster, J. (2003). Slum Upgrading and Participation: Lessons from Latin America. Washington D.C.: World Bank.

Ingham, B. (1993). The meaning of development: Interactions between "new" and "old" ideas. World Development, 21(11), 1803-1821. https://doi.org/10.1016/0305-750X(93)90084-M

Jacobus, R. (2015). Inclusionary housing: creating \& maintaining inclusive communities (Policy Focus Report). Cambridge, MA: Lincoln Institute of Land Policy.

Jones, P. (2005). Managing urban development in the Pacific: key themes and issues. Australian Planner, 42(1), 39-46.

Jones, P. (2007). Placing urban management and development on the Pacific Island. Australian Planner, 44(1), 13-15.

Jones, P. (2012). Pacific Urbanisation and the rise of informal settlements: trends and implications from Port Moresby. Urban Policy and Research, 30(2), 145160.

Karki, T. K. (2004). Implementation experiences of land pooling projects in Kathmandu Valley. Habitat International, 28(1), 67-88. https://doi.org/10.1016/S0197-3975(02)00085-1

Kirbyshire, A., Wilkinson, E., \& Le Masson, V. (2017). Mass displacement and the challenge for urban resilience (Working Paper). London: Overseas Development Institute.

Kronenberg, R. P., \& Khor, H. E. (2016). Economic growth in the Pacific Island Countries - challenges, constraints, and policy responses. In H. E. Khor, R. P. Kronenberg, \& P. Tumbarello (Eds.), Resilience and growth in the small states of the Pacific (pp. 3-13). Washington, D.C.: International Monetary Fund.

La Croix, S. (2016). New Perspectives on Land and Housing Markets in Hawaii: Implications for Industrial and Commercial Land Leasing. Honolulu, HI: UHERO-The Economics Research Organization at the University of Hawai'i. Retrieved

from https://pdfs.semanticscholar.org/2e3d/2c9df65b2eac7b570d984cd4a576d447a 1a6.pdf

La Croix, S. J., Mak, J., \& Rose, L. A. (1995). The political economy of urban land reform in Hawaii. Urban Studies, 32(6), 999-1015.

Larsson, G. (1997). Land readjustment: A tool for urban development. Habitat International, 21(2), 141-152. https://doi.org/10.1016/S0197-3975(96)000598 
Das: DEVELOPMENT AND SHELTER CHALLENGES OF SMALL ISLANDS: PLANNING WITH A PROPOOR PERSPECTIVE

Legates, R., \& Hudalah, D. (2014). Peri-Urban Planning for Developing East Asia: Learning from Chengdu, China and Yogyakarta/Kartamantul, Indonesia. Journal of Urban Affairs, n/a-n/a. https://doi.org/10.1111/juaf.12106

Lewis, B. D. (2010). Indonesian Decentralization: Accountability Deferred. International Journal of Public Administration, 33(12-13), 648-657. https://doi.org/10.1080/01900692.2010.514442

Lindquist, J. (2010). Labour recruitment, circuits of capital and gendered mobility: Reconceptualizing the Indonesian migration industry. Pacific Affairs, 83(1), $115-132$.

Lindsey, R. (1988, March 18). Japanese Riding Hawaii's Real Estate Boom. The New York Times. Retrieved from https:/www.nytimes.com/1988/03/18/us/japanese-riding-hawaii-s-real-estateboom.html

Mahadevia, D., Pai, M., \& Mahendra, A. (2018). Ahmedabad: Town Planning Schemes for Equitable Development - Glass Half Full or Half Empty? (Case study). Washington, D.C.: World Resources Institute. Retrieved from https://www.wri.org/wri-citiesforall/publication/ahmedabad-town-planningschemes-equitable-development-glass-half-full

Mak, J. (2008). Developing a Dream Destination: Tourism and Tourism Policy Planning in Hawai ' $i$. Honolulu, HI: University of Hawaii Press.

Mak, J. (2015). Creating "Paradise of the Pacific": How Tourism Began in Hawaii (Working Paper No. 2015-1). Honolulu, HI: UHERO-The Economics Research Organization at the University of Hawai'i. Retrieved from http://www.economics.hawaii.edu/research/workingpapers/WP_15-3.pdf

Mansuri, G., \& Rao, V. (2004). Community-based and -driven development: a critical review. The World Bank Research Observer, 19(1), 1-39. https://doi.org/10.1093/wbro/lkh012

Mansuri, G., \& Rao, V. (2013). Localizing development: does participation work? Washington, D.C: World Bank.

Martine, G., McGranahan, G., Montgomery, M., \& Fernández-Castilla, R. (Eds.). (2008). The new global frontier: urbanization, poverty and environment in the 21st century. London; Sterling, VA: Earthscan.

Mathur, O. P. (2013). Urban poverty in Asia. Mandaluyong City, Philippines: Asian Development Bank.

Mathur, S. (2015). Sale of development rights to fund public transportation projects: Insights from Rajkot, India, BRTS project. Habitat International, 50, 234239. https://doi.org/10.1016/j.habitatint.2015.08.041

Mathur, S., \& Smith, A. (2013). Land value capture to fund public transportation infrastructure: Examination of joint development projects' revenue yield and stability. Transport Policy, 30, 327-335. https://doi.org/10.1016/j.tranpol.2013.09.016

Mayo, S. K., \& Gross, D. J. (1987). Sites and Services - and Subsidies: The Economics of Low-Cost Housing in Developing Countries. The World Bank Economic Review, 1(2), 301-335. https://doi.org/10.1093/wber/1.2.301 
McGillivray, M., Naudé, W., \& Santos-Paulino, A. (2008). Small island states development challenges: introduction. Journal of International Development, 20(4), 481-485. https://doi.org/10.1002/jid.1476

Minerbi, L. (2011). Hawai'i, USA. In G. Baldacchino (Ed.), Managing heritage in extreme environments (pp. 152-174). New York, Oxford: Berghahn Books.

Miraftab, F. (2004). Public-Private Partnerships: The Trojan Horse of Neoliberal Development? Journal of Planning Education and Research, 24(1), 89-101. https://doi.org/10.1177/0739456X04267173

Monkkonen, P. (2011). The Housing Transition in Mexico Expanding Access to Housing Finance. Urban Affairs Review, 47(5), 672-695. https://doi.org/10.1177/1078087411400381

Mukhija, V. (2003). Squatters as developers?:slum redevelopment in Mumbai. Aldershot, Hampshire, England; Burlington, VT: Ashgate.

Mukhija, V. (2016). Rehousing Mumbai: formalizing slum land markets through redevelopment. In E. L. Birch, S. Chattaraj, \& S. M. Wachter (Eds.), Slums: how informal real estate markets work. Philadelphia: University of Pennsylvania Press.

Mukhija, V., Das, A., Regus, L., \& Tsay, S. S. (2015). The Tradeoffs of Inclusionary Zoning: What Do We Know and What Do We Need to Know? Planning $\begin{array}{llll}\text { Practice } \quad \text { R } & \text { 20search, } & \text { 222-235. }\end{array}$ https://doi.org/10.1080/02697459.2015.1008793

Nowak, J.-J., \& Sahli, M. (2007). Coastal tourism and "Dutch disease" in a small island economy. Tourism Economics, 13(1), 49-65.

Omaye, J. (2017, February 22). City Council considers expanding 'sit-lie' ban areas. Honolulu Star-Advertiser. Retrieved http://www.staradvertiser.com/2017/02/22/hawaii-news/city-councilconsiders-expanding-sit-lie-ban-areas/

Parks, V., \& Warren, D. (2009). The politics and practice of economic justice: Community benefits agreements as tactic of the new accountable development movement. Journal of Community Practice, 17(1-2), 88-106.

Payne, G. (2001). Lowering the ladder: regulatory frameworks for sustainable development. Development in Practice, 11(2-3), 308-318.

Payne, G., Durand-Lasserve, A., \& Rakodi, C. (2009). The limits of land titling and home ownership. Environment and Urbanization, 21(2), 443-462. https://doi.org/10.1177/0956247809344364

PBS. (2013). Paradise found: A history of pineapple, sugar and seeds in Hawaii. Retrieved August 26, 2017, from http://www.pbs.org/newshour/rundown/paradise-found-hawaiian-agriculturefrom-sugar-cane-to-seed-farms/

Peattie, L. (1983). Realistic planning and qualitative research. Habitat International, 7(5-6), 227-234.

Peattie, L. R. (1987). Affordability. Habitat International, 11(4), 69-76.

Peattie, L. R. (1994). An argument for slums. Journal of Planning Education and Research, 13(2), 136-143. 
Das: DEVELOPMENT AND SHELTER CHALLENGES OF SMALL ISLANDS: PLANNING WITH A PROPOOR PERSPECTIVE

Peck, J., Theodore, N., \& Brenner, N. (2013). Neoliberal Urbanism Redux? International Journal of Urban and Regional Research, 37(3), 1091-1099. https://doi.org/10.1111/1468-2427.12066

Peters, R. (2013). Surabaya, 1945-2010: neighbourhood, state and economy in Indonesia's city of struggle. Singapore: National University of Singapore Press.

Plummer, J. (2002). Focusing partnerships: a sourcebook for municipal capacity building in public-private partnerships. London; Sterling, VA: Earthscan Publications.

Rajalingam, G. (2014). 2014 Survey of Travelers to Timor-Leste (Research Report). Dili, Timor-Leste: The Asia Foundation. Retrieved from http://asiafoundation.org/publication/2014-survey-of-travelers-to-timor-leste/

Rakodi, C., \& Lloyd-Jones, T. (Eds.). (2002). Urban livelihoods: a people-centred approach to reducing poverty. London; Sterling, VA: Earthscan Publications. Retrieved from http://site.ebrary.com/id/10128883

Ravallion, M., Chen, S., \& Sangraula, P. (2007). New Evidence on the Urbanization of Global Poverty. Population and Development Review, 33(4), 667-701. https://doi.org/10.1111/j.1728-4457.2007.00193.x

Read, R. (2004). The Implications of Increasing Globalization and Regionalism for the Economic Growth of Small Island States. World Development, 32(2), 365378. https://doi.org/10.1016/j.worlddev.2003.08.007

Read, R. (2008). Foreign direct investment in small island developing states. Journal of International Development, 20(4), 502-525. https://doi.org/10.1002/jid.1477

Rimmer, P. J., \& Dick, H. W. (2009). The city in Southeast Asia: patterns, processes, and policy. Singapore: NUS Press.

Rolnik, R. (2014). Place, inhabitance and citizenship: the right to housing and the right to the city in the contemporary urban world. International Journal of Housing Policy, 14(3), 293-300. https://doi.org/10.1080/14616718.2014.936178

Rondinelli, D. A., McCullough, J. S., \& Johnson, R. W. (1989). Analysing Decentralization Policies in Developing Countries: a Political-Economy Framework. Development and Change, 20(1), 57-87. https://doi.org/10.1111/j.1467-7660.1989.tb00340.x

Roy, A. (2005). Urban informality: Towards an Epistemology of Planning. Journal of the American Planning Association, 71(2), 147-158.

Roy, A., \& Ong, A. (Eds.). (2011). Worlding cities: Asian experiments and the art of being global. Oxford, UK: John Wiley \& Sons.

Salanto, F. (2015). Surabaya property market report (Research and Forecast Report No. H2 2015). Jakarta, Indonesia: Colliers International Indonesia.

Sanyal, B., \& Mukhija, V. (2001). Institutional Pluralism and Housing Delivery: A Case of Unforeseen Conflicts in Mumbai, India. World Development, 29(12), 2043-2057. https://doi.org/10.1016/S0305-750X(01)00082-1 
Satterthwaite, D. (2013). The political underpinnings of cities' accumulated resilience to climate change. Environment and Urbanization, 25(2), 381-391. https://doi.org/10.1177/0956247813500902

Satterthwaite, D., \& Mitlin, D. (2014). Reducing urban poverty in the global South. London; New York: Routledge.

Schneider, F., \& Enste, D. H. (2016). The shadow economy: an international survey. New York: Cambridge University Press.

Sen, S. (1999). Some Aspects of State-NGO Relationships in India in the PostIndependence Era. Development and Change, 30(2), 327-355. https://doi.org/10.1111/1467-7660.00120

Shih, M., \& Chang, H. B. (2016). Transfer of development rights and public facility planning in Taiwan: An examination of local adaptation and spatial impact. Urban Studies, 53(6), 1244-1260. https://doi.org/10.1177/0042098015572974

Silas, J. (1984). The Kampung Improvement Programme of Indonesia: a comparative case study of Jakarta and Surabaya. In G. K. Payne (Ed.), Lowincome housing in the developing world: The role of sites and services and settlement Upgrading. (pp. 69-87). New York: John Wiley \& Sons.

Silver, C. (2005). Do the donors have it right? Decentralization and changing local governance in Indonesia. In H. W. Richardson \& C.-H. C. Bae (Eds.), Globalization and Urban Development (pp. 95-108). Berlin; Heidelberg: Springer. Retrieved from http://www.springerlink.com/content/g814353781k880k4/abstract/

Smets, S. (2015). Water supply and sanitation in Timor-Leste: turning finance into services for the future (Working Paper (service develivery assessment) No. 100895). Washington, D.C.: Water and Sanitation Program, World Bank Group.

Smolka, M. O. (2013). Implementing Value Capture in Latin America: Policies and Tools for Urban Development (Policy Focus Report). Cambridge, MA: Lincoln Institute of Land Policy. Retrieved from http://www.lincolninst.edu/publications/policy-focus-reports/implementingvalue-capture-latin-america

SMS. (2016). Hawaii Housing Planning Study (2016). Honolulu, HI: Department of Housing and Human Concerns, County of Maui \& SMS Research and Marketing Services, Inc.

Sorensen, A. (2000). Conflict, consensus or consent: implications of Japanese land readjustment practice for developing countries. Habitat International, 24(1), 51-73. https://doi.org/10.1016/S0197-3975(99)00029-6

Stein, S. M., Carr, M. A., Liknes, G. C., \& Comas, S. J. (2014). Islands on the edge: housing development and other threats to America's Pacific and Caribbean Island forests (General Technical Report No. NRS-137). Newtown Square, PA: United States Department of Agriculture, Forest Service, Northern Research Station.

Sumka, H. J. (1987). Shelter Policy and Planning in Developing Countries: Introduction. Journal of the American Planning Association, 53(2), 171-175. https://doi.org/10.1080/01944368708976649 
Das: DEVELOPMENT AND SHELTER CHALLENGES OF SMALL ISLANDS: PLANNING WITH A PROPOOR PERSPECTIVE

Tacoli, C., McGranahan, G., \& Satterthwaite, D. (2015). Urbanisation, rural-urban migration and urban poverty (Working Paper No. 10725IIED). London: International Institute for Environment and Development (IIED).

Tian, E. (2014, May). What are the economic drivers for Hawaii in 2014 and beyond. Presented at the Realtor Housing Forum, Honolulu, HI. Retrieved from files.hawaii.gov/dbedt/economic/reports/2014-economic-drivers.pdf

Tipple, G. (2005). The Place of Home-based Enterprises in the Informal Sector: Evidence from Cochabamba, New Delhi, Surabaya and Pretoria. Urban Studies, 42(4), 611-632. https://doi.org/10.1080/00420980500060178

Tunas, D., \& Darmoyono, L. T. (2014). Self-help housing in Indonesia. In J. Bredenoord, P. van Lindert, \& P. Smets (Eds.), Affordable housing in the urban Global South: seeking sustainable solutions (pp. 166-180). New York: Routledge.

Turner, J. F. C. (1968). Housing Priorities, Settlement Patterns, and Urban Development in Modernizing Countries. Journal of the American Institute of Planners, 34(6), 354-363. https://doi.org/10.1080/01944366808977562

Turner, J. F. C. (1976). Approaches to government-sponsored housing. Ekistics, 41(242), 4-7.

Turner, J. F. C., \& Fichter, R. (Eds.). (1972). Freedom to Build. New York: Macmillan.

UN-HABITAT. (2003). The challenge of slums: Global report on human settlements 2003. London; Sterling, VA: Earthscan Publications.

UN-HABITAT. (2010). The State of Asian cities 2010/11. Fukuoka, Japan: United Nations Human Settlements Programme.

UN-HABITAT. (2012). The Community Land Trusts: Affordable Access to Land and Housing. Nairobi, Kenya: United Nations Human Settlements Programme (UN-HABITAT). Retrieved from https://unhabitat.org/books/community-landtrusts-affordable-access-to-land-and-housing/

UN-HABITAT. (2015). Urbanization and Climate Change in Small Island Developing States. Nairobi, Kenya: United Nations Human Settlements Programme (UN-HABITAT). from https://unhabitat.org/books/urbanization-and-climate-change-in-small-islanddeveloping-states/

UN-HABITAT. (2016). Urbanization and development: emerging futures (World Cities Report 2016). Nairobi, Kenya: United Nations Human Settlements Programme (UN-HABITAT).

UN-HABITAT, \& UNESCAP. (2008). Land: A crucial element in housing the urban poor (Housing the poor in Asian cities No. Quick Guide 3). Bangkok, Thailand; Nairobi, Kenya: United Nations Economic and Social Commission for Asia and the Pacific (UNESCAP), and United Nations Human Settlements Programme (UN-HABITAT). from https://unhabitat.org/books/quick-guide-3-land-a-crucial-element-in-housingthe-urban-poor/

United Nations. (2017). New Urban Agenda. New York: United Nations. 
UNWTO. (2012). Challenges and opportunities for tourism development in small island developing states. Madrid: United Nations World Tourism Organisation.

Urresta, E., \& Nixon, R. (2004). Report on research findings, policy options, and recommendations for a law on land rights and title restitution. East Timor Land Law Program.

USAID. (2012). Timor-Leste (USAID Country Profile, Property Rights and Resource Governance). Washington, D.C.: United States Agency for International Development (USAID). Retrieved from http://www.usaidltpr.com/timor-leste

Wade, R. H. (2004). Is globalization reducing poverty and inequality? World Development, 32(4), 567-589.

Wallis, J., \& Thu, P. M. (2013, November 27). The difficulties of development in Timor-Leste. Retrieved September 3, 2017, from http://devpolicy.org/thedifficulties-of-development-in-timor-leste-20131127/

Werlin, H. (1999). The slum upgrading myth. Urban Studies, 36(9), 1523.

World Bank. (2003). World Development Report 2003. Washington, D.C. and New York: The World Bank and Oxford University Press. Retrieved from http://elibrary.worldbank.org/doi/book/10.1596/0-8213-5150-8

World Bank. (2012). Indonesia - The rise of metropolitan regions: towards inclusive and sustainable regional development (No. 71740) (pp. 1-141). Jakarta, Indonesia: The World Bank. Retrieved from http://documents.worldbank.org/curated/en/2012/08/16587797/indonesia-risemetropolitan-regions-towards-inclusive-sustainable-regional-development

World Bank. (2013). Timor-Leste Social Assistance: Public Expenditure and Program Performance Report (Technical Assistance Performance Evaluation Report No. 73484- TP). Washington, D.C.: World Bank.

World Bank. (2015). East Asia's changing urban landscape: measuring a decade of spatial urban growth (Urban Development Series). Washington, DC. 
Das: DEVELOPMENT AND SHELTER CHALLENGES OF SMALL ISLANDS: PLANNING WITH A PROPOOR PERSPECTIVE

This Page is Intentionally Left Blank 